\title{
Emissions of terpenoids, benzenoids, and other biogenic gas-phase organic compounds from agricultural crops and their potential implications for air quality
}

\author{
D. R. Gentner ${ }^{1, *}$, E. Ormeño ${ }^{2,3}$, S. Fares ${ }^{2,4}$, T. B. Ford ${ }^{5}$, R. Weber ${ }^{2}$, J.-H. Park ${ }^{2}$, J. Brioude ${ }^{6,7}$, W. M. Angevine ${ }^{6,7}$, \\ J. F. Karlik ${ }^{8}$, and A. H. Goldstein ${ }^{1,2}$ \\ ${ }^{1}$ Department of Civil and Environmental Engineering, University of California, Berkeley, CA 94720, USA \\ ${ }^{2}$ Department of Environmental Science, Policy and Management, University of California, Berkeley, CA 94720, USA \\ ${ }^{3}$ Aix-Marseille Université - Institut méditerranéen de biodiversité et écologie IMBE CNRS UMR 7263, France \\ ${ }^{4}$ Consiglio per la Ricerca e la sperimentazione in Agricoltura (CRA)- Research Centre for the Soil-Plant System, Rome, Italy \\ ${ }^{5}$ Department of Chemistry University of California, Berkeley, CA 94720, USA \\ ${ }^{6}$ Cooperative Institute for Research in Environmental Sciences, University of Colorado, Boulder, CO 80309, USA \\ ${ }^{7}$ Chemical Sciences Division, Earth System Research Laboratory, National Oceanic and Atmospheric Administration, \\ Boulder, CO 80305, USA \\ ${ }^{8}$ University of California Cooperative Extension, Kern County, CA, USA \\ *now at: Department of Chemical \& Environmental Engineering, Yale University, New Haven, CT 06511, USA
}

Correspondence to: D. R. Gentner (drew.gentner@yale.edu)

Received: 9 September 2013 - Published in Atmos. Chem. Phys. Discuss.: 1 November 2013

Revised: 28 March 2014 - Accepted: 11 April 2014 - Published: 3 June 2014

\begin{abstract}
Agriculture comprises a substantial, and increasing, fraction of land use in many regions of the world. Emissions from agricultural vegetation and other biogenic and anthropogenic sources react in the atmosphere to produce ozone and secondary organic aerosol, which comprises a substantial fraction of particulate matter $\left(\mathrm{PM}_{2.5}\right)$. Using data from three measurement campaigns, we examine the magnitude and composition of reactive gas-phase organic carbon emissions from agricultural crops and their potential to impact regional air quality relative to anthropogenic emissions from motor vehicles in California's San Joaquin Valley, which is out of compliance with state and federal standards for tropospheric ozone $\mathrm{PM}_{2.5}$. Emission rates for a suite of terpenoid compounds were measured in a greenhouse for 25 representative crops from California in 2008. Ambient measurements of terpenoids and other biogenic compounds in the volatile and intermediate-volatility organic compound ranges were made in the urban area of Bakersfield and over an orange orchard in a rural area of the San Joaquin Valley during two 2010 seasons: summer and spring flowering. We combined measurements from the orchard site with ozone mod-
\end{abstract}

eling methods to assess the net effect of the orange trees on regional ozone. When accounting for both emissions of reactive precursors and the deposition of ozone to the orchard, the orange trees are a net source of ozone in the springtime during flowering, and relatively neutral for most of the summer until the fall, when it becomes a sink. Flowering was a major emission event and caused a large increase in emissions including a suite of compounds that had not been measured in the atmosphere before. Such biogenic emission events need to be better parameterized in models as they have significant potential to impact regional air quality since emissions increase by several factors to over an order of magnitude. In regions like the San Joaquin Valley, the mass of biogenic emissions from agricultural crops during the summer (without flowering) and the potential ozone and secondary organic aerosol formation from these emissions are on the same order as anthropogenic emissions from motor vehicles and must be considered in air quality models and secondary pollution control strategies. 


\section{Introduction}

Biogenic compounds are emitted from vegetation via several mechanisms and pathways. Emissions are typically a function of environmental parameters (e.g., light, temperature) or specialized responses to communicate with, attract, or repel animals, insects, or other plants (Bouvier-Brown et al., 2009; Goldstein and Galbally, 2007). Biogenic emissions from plants are mostly in the gas phase and span from 1 to over 20 carbon atoms in size (Goldstein and Galbally, 2007). Examples include small compounds such as methanol and acetone, and a broad suite of isomers that are multiples of isoprene $\left(\mathrm{C}_{5} \mathrm{H}_{8}\right)$. Prominent examples of these olefinic compound classes include monoterpenes $\left(\mathrm{C}_{10} \mathrm{H}_{16}\right)$ and sesquiterpenes $\left(\mathrm{C}_{15} \mathrm{H}_{24}\right)$. Their oxygenated counterparts contain 1-2 oxygen atoms and are included in the definition of monoterpenoids and sesquiterpenoids. Plant species can emit a variety of these isomers with one or more double bonds and can include cyclic or bicyclic rings, but a certain suite of compounds has been observed more frequently (Bouvier-Brown et al., 2009; Goldstein and Galbally, 2007). Commonly reported monoterpenes include $\Delta$-limonene, $\alpha$-pinene, and $\Delta 3$-carene; common sesquiterpenes, which are more difficult to measure, include $\beta$-caryophyllene and $\alpha$-humulene (Bouvier-Brown et al., 2009; Helmig et al., 2006; Ormeno et al., 2007, 2010). Many terpenoids have specific functions and are responsible for the fragrances and flavors associated with various plants (Bouvier-Brown et al., 2009; Lewis et al., 2007; Afsharypuor and Jamali, 2006; Bendimerad et al., 2007; Bernhardt et al., 2003; Azuma et al., 2001; Omura et al., 1999; Kotze et al., 2010). Some studies have also shown plant leaves or flowers to contain other compounds with aromatic rings (i.e., benzenoids) and nitrogen- or sulfur-based functional groups (Lewis et al., 2007; Afsharypuor and Jamali, 2006; Bendimerad et al., 2007; Bernhardt et al., 2003; Azuma et al., 2001; Omura et al., 1999; Kotze et al., 2010; Ormeno et al., 2010).

Much work has been done to understand emissions of biogenic gas-phase organic carbon since most of the compounds are highly reactive and can produce ozone $\left(\mathrm{O}_{3}\right)$ and secondary organic aerosol (SOA) as a product of their chemistry with atmospheric oxidants (Carter, 2007; Ng et al., 2006). Studies on gas-phase organics in the past decade have observed evidence for unknown biogenic emissions that could not be chemically resolved (Di Carlo et al., 2004; Holtzinger et al., 2005). Subsequent research has expanded the range of measurements (Bouvier-Brown et al., 2009; Helmig et al., 2006; Ormeno et al., 2007, 2010), and further characterization remains necessary. Additionally, understanding emissions from vegetation is important because of the complex interplay of anthropogenic emissions and biogenic emissions from both natural vegetation and agricultural crops, in California and globally (Spracklen et al., 2011; Shilling et al., 2013). Agricultural plantings make up a major fraction of land cover in some regions such as California's San Joaquin
Table 1. Planted areas for permanent crops with largest land cover in the San Joaquin Valley.

\begin{tabular}{lr}
\hline Crop & Acreage \\
\hline Cotton & 653000 \\
Maize & 501000 \\
Almonds & 453000 \\
Grapes (raisin varieties) & 241000 \\
Tomatoes & 222000 \\
Walnuts & 124000 \\
Navel oranges & 124000 \\
Pistachios & 97024 \\
Grapes (table varieties) & 84900 \\
Peaches & 51300 \\
Apples & 15800 \\
\hline
\end{tabular}

Data from 2002 crop reports, respective county agriculture commissioners' offices.

Valley (Fig. S1), which is an extreme non-attainment area for ozone and a non-attainment area for $\mathrm{PM}_{2.5}$ (US EPA). A summary of prominent agricultural crops in the San Joaquin Valley is shown in Table 1. Historically, there has been some research on emissions from agricultural crops in California (Arey et al., 1991a, b, c, d; Winer et al., 1989; Winer et al., 1992; Karlik et al., 2002). However, biogenic emissions from many of these crops and other agricultural plants require further characterization with new advances in instrumentation and contemporary scientific knowledge and concerns. Also, total emissions have previously been thought to be minor relative to natural vegetation (Lamb et al, 1987), and further measurements of terpenoid emissions are necessary to build upon previous work. Models on regional scales, and larger, need this information on emission factors from individual plant species to improve parameterizations; these include the MEGAN (Model of Emissions of Gases and Aerosols from Nature) model (Sakulyanontvittaya et al., 2008; Guenther et al., 2012) and the BEIGIS (Biogenic Emission Inventory Geographic Information System) model developed by the California Air Resources Board (2003).

This work includes a survey of volatile organic compound (VOC) and intermediate-volatility organic compound (IVOC) emissions from agricultural crops studied via plant enclosure measurements in a greenhouse to develop emission factors and emission parameters (Table 2), and also an assessment of seasonal emissions from an orange orchard located in a rural area of the San Joaquin Valley. Further objectives of this work include characterizing emissions associated with spring flowering, examining the relative importance of biogenic emissions from agriculture on ozone and SOA formation in the San Joaquin Valley, and modeling the net effect of orange trees in our case study orchard on ambient ozone concentrations. 


\section{Materials and methods}

This paper uses measurements from three campaigns: a survey using plant and branch enclosures in a greenhouse, a multi-season campaign in an orange orchard, and an urban site in Bakersfield, CA. The principle gas-phase organic carbon measurements in this work were made using a custom gas chromatograph with a mass spectrometer and a flame ionization detector (GC/MS-FID). A broad suite of several hundred compounds was quantified with hourly time resolution. Extensive detail on the design and operation of the instrument can be found in Gentner et al. (2012).

To examine emissions from agricultural vegetation, 25 different crops were studied in the partially controlled environment of the Oxford Tract greenhouse at UC Berkeley during the summer of 2008 (all experiment design details available in Fares et al., 2011). The crops included a mixture of woody trees and shrubs, as well as herbaceous plants that are prominent in California (Table S1), with emissions from 2 to 8 individual plants measured for each species. Plants were all potted, fertilized weekly, and watered daily to provide good growing conditions and avoid water stress. Plants were exposed to natural sunlight and the greenhouse humidity was maintained at $40-60 \%$. Depending on plant size, branches or whole plants were enclosed in custom Teflon chambers outfitted with temperature and light monitors, and supplied with purified "zero" air (Aadco model 737) enriched with carbon dioxide. Measurements were performed for several days at a time, with additional replicates of each species. To avoid any biases caused by plant damage during enclosure, plants were given time to equilibrate before measurements were used to assess emission rates and chemical speciation. In addition to chemically speciated measurements of VOCs and IVOCs via gas chromatography-mass spectrometry, several other instruments were used to measure ozone, carbon dioxide, and water vapor. Measurements of isoprene and monoterpenes reported from greenhouse enclosure measurements were made in conjunction with a high-time-resolution proton transfer reaction mass spectrometer (PTR-MS) (Fares et al., 2011).

Following the greenhouse study wherein orange trees were among the largest emitters, a yearlong measurement site was set up in a Valencia orange orchard in the San Joaquin Valley $\left(36.3566^{\circ} \mathrm{N}, 119.0923^{\circ} \mathrm{W}\right)$. The site was located in Lindcove, which is east of the city of Visalia near the foothills of the Sierra Nevada. The local area around the site had a large planted area of various citrus trees and some other crops. In addition to biogenic emissions from nearby agriculture, the site was influenced by natural vegetation in the surrounding mountains and anthropogenic sources in the San Joaquin Valley. A detailed description of the site can be found in Fares et al. (2012b). We took two sets of chemically speciated organic carbon measurements at this site during two different seasons: in April-May 2010 during citrus flowering and summer 2010 (each 10 or more days). Measurements were made at the top of the canopy $(4 \mathrm{~m})$, and the site had a similar suite of supporting measurements as the greenhouse study. Yearlong measurements of ozone fluxes over the orange orchard are used in this work; these methods have been described elsewhere (Fares et al., 2012b).

Ambient in situ measurements were made in Bakersfield, $\mathrm{CA}$, at the CalNex (California Research at the Nexus of Air Quality and Climate Change) supersite $\left(35.3463^{\circ} \mathrm{N}\right.$, $118.9654^{\circ} \mathrm{W}$ ) located in southeastern Bakersfield in the southern San Joaquin Valley. Measurement of gas-phase organics took place during the period of 18 May-30 June 2010, sampled from the top of an $18 \mathrm{~m}$ tower. To reduce losses of highly reactive compounds in the sampling system, ozone was removed at the inlet using sodium thiosulfate-treated filters at both ambient measurement sites (discussed in Gentner et al., 2012).

We recently developed a method in Gentner et al. (2014) that calculates the spatial distribution of emissions in a region based on fixed-location measurements and coincident footprints for each hourly sample determined using the FLEXPART-WRF Lagrangian model for meteorological modeling (Brioude et al., 2012). Extensive details on the methodology can be found in Gentner et al. (2014). In this work, we use it to examine the transport of biogenic VOCs to the urban site in the southern San Joaquin Valley.

Basal emission factors (BEFs) are the standardized emission factors for biogenic compounds from vegetation, and are adjusted based on the environmental parameters considered. BEFs were calculated for each compound class for each plant species studied in the greenhouse by taking the average of the data points with temperature $=30 \pm 2{ }^{\circ} \mathrm{C}$, and photosynthetically active radiation (PAR) $>800 \mu \mathrm{mol} \mathrm{m}^{-2} \mathrm{~s}^{-1}$. These emission rates, or fluxes, are reported in carbon mass

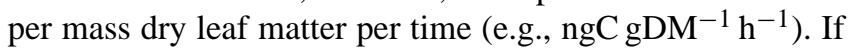
insufficient data existed at these basal conditions, data were logarithmically extrapolated from lower temperature data to determine BEFs (see Fares et al. (2011) for details).

Most compounds without specialized functions can be characterized by two different emission mechanisms, described as dependence on light and temperature or just temperature. Compounds that are emitted immediately after being produced in the leaves are light and temperature dependent, and their emission rates are calculated using the method developed by Guenther et al. (1993). However, emissions based solely on temperature are kept in storage pools inside the leaves and/or stems, and are emitted via volatilization. These emission rates are calculated based on methods in Tingey et al. (1980) and Guenther et al. (1993). Not all compounds are emitted by a single pathway, so we test both methods of emission characterization with the same calculated BEF. Additional information, including the equations used (S1-S2), can be found in the supplementary material. For both methods, calculated emission rates from the greenhouse enclosure studies were compared to measured rates via linear correlation. The resulting slopes and coefficients 
of determination $\left(r^{2}\right)$ are reported to describe how accurately each method models the emissions from each plant and compound class in this study.

At the Lindcove and Bakersfield sites, comparisons of biogenic to anthropogenic burdens of gas-phase organic carbon were done using chemical mass balance source receptor modeling methods (Gentner et al., 2012) to model anthropogenic emissions from motor vehicles. Total emissions of anthropogenic hydrocarbons in the San Joaquin Valley from motor vehicles are determined using the emission factors derived in Gentner et al. (2012) and fuel use data for the seven counties in the air basin (California Dept. Transportation, 2008). Our estimates of biogenic emissions for the region were compared to the California Air Resources Board emission inventory (2010). The ozone formation potential of these emissions are compared as maximum incremental reactivity (MIR) values for each compound (or compound class) calculated by Carter (2007) using the SAPRC (Statewide Air Pollution Research Center) chemical mechanism. Existing information on yields of secondary organic aerosol from atmospheric oxidation are compiled from the literature (Gentner et al., 2012; Saathoff et al., 2009; Kim et al., 2012; Ng et al., 2006). Where available, literature values are presented for reaction constants of atmospheric oxidants with the biogenic compounds measured in this study (Atkinson and Arey, 2003a, b). Otherwise, for newly measured compounds, theoretical values are estimated using the US EPA's EPI Suite program (2000).

\section{Results and discussion}

\subsection{Greenhouse measurements of individual plant species}

There were numerous terpenoid compounds quantified in emissions from crops with considerable diversity of emissions between plant species. Emission parameters and detailed chemical speciation for monoterpenes, oxygenated monoterpenes, and sesquiterpenes measured from the different crops in the greenhouse study are shown in Tables 2 and S2-S5. With the exception of two orange trees, all plants were in a non-flowering state. Monoterpene concentrations were measured as individual species via gas chromatography and as total monoterpenes with the PTR-MS, and agreed to within $20 \%$ (Fares et al., 2011). In addition to the wellknown monoterpenes $\Delta$-limonene and $\alpha$-pinene, there were similar magnitude emission factors for $\beta$-myrcene, sabinene, and both isomers of $\beta$-ocimene. Oxygenated monoterpene emissions were dominated by linalool and perillene, a littlestudied furanoid. We observed only two sesquiterpenes, $\alpha$ humulene and $\beta$-caryophyllene, from the crops studied. Consistent with previous work, $\beta$-caryophyllene dominated the two, but it is likely that there were other sesquiterpenes outside of the observable range, at concentrations below the limit of detection, or lost in the sampling system prior to detection. A broader suite of sesquiterpenes was measured using a cartridge method and emission factors are reported by Ormeno et al. (2010).

Calculated BEFs and beta values for total monoterpenes, oxygenated monoterpenes, and sesquiterpenes are summarized in Table 2 with relevant statistical metrics. Data on the chemical speciation of emissions and the performance of the temperature-only and light + temperature modeling methods are shown in Tables S2-S5. Compared to other natural vegetation (e.g., oak trees, poplar) agricultural crops have low isoprene emission factors. This work focuses on the larger emissions of terpenoids, but a summary of observed isoprene fluxes can be found in Tables S6-S7 along with emission factors for methanol, acetaldehyde, and acetone. While it is conventionally helpful to group plants together for the purposes of modeling based on either emissions strength or crop type, we have refrained from doing so in this work. There is a considerable amount of uncertainty in the individual emission factors and the relative strength of emissions varies for each plant species depending on chemical class. Such a grouping would be subject to the limitations of this study and, in some cases, regional assumptions.

\subsubsection{Monoterpenes}

Total emissions of monoterpenes were lowest $\left(<100 \mathrm{ngC} \mathrm{gDM}^{-1} \mathrm{~h}^{-1}\right)$ from almond, grape, olive, pistachio, plum, and pomegranate (Table 2). For almond and cherry, the monoterpene BEF agreed with previous research (Winer et al., 1992). Emissions from grapes were very low (11 and $91 \mathrm{ngC} \mathrm{gDM}^{-1} \mathrm{~h}^{-1}$ ), and Winer et al. (1992) did not detect any emissions. The monoterpene BEF for peach, $1211 \mathrm{ngC} \mathrm{gDM}^{-1} \mathrm{~h}^{-1}$, was significantly higher than other plants in the Prunus genus (i.e., almond, plum) measured in this study.

Correlations between measured and modeled monoterpene emissions for both the temperature-only and the light + temperature modeling methods were significant for almond and olive (Table S2). Some plant species, such as the above-mentioned, are known to have storage structures on their leaves where terpenes are typically stored (Vieira et al., 2001). The existence of these "pools" of biogenic compounds is relevant since harvesting or pruning may cause emissions if leaves are damaged during agricultural operations.

Among the herbaceous species, tomato was the highest monoterpene emitter $\left(\mathrm{BEF}=742 \mathrm{ngC} \mathrm{gDM}^{-1} \mathrm{~h}^{-1}\right)$. The measured BEF was within the range of previously reported values for tomato (Winer et al., 1992; Jansen et al., 2008). Tomato is well known to have specialized structures (Freitas et al. 2002; van Schie et al. 2007) filled with terpenes, and the emissions have been shown to dramatically increase after wounding or pathogen infestation (Jansen et al., 2008), 
Table 2. Basal emission factors (ngC $\left.\mathrm{gDM}^{-1} \mathrm{~h}^{-1}\right)$ and beta values for monoterpenes, oxygenated monoterpenes, and sesquiterpenes from enclosure studies ( $N$ is the sample size and $r$ the correlation coefficient).

\begin{tabular}{|c|c|c|c|c|c|c|}
\hline \multirow[b]{2}{*}{ Crop } & \multicolumn{2}{|c|}{ Monoterpenes } & \multicolumn{2}{|c|}{ Oxygenated monoterpenes } & \multicolumn{2}{|c|}{ Sesquiterpenes } \\
\hline & $\mathrm{BEF} \pm \mathrm{SD}(N)$ & $\operatorname{Beta}(r)(N)$ & $\mathrm{BEF} \pm \mathrm{SD}(N)$ & $\operatorname{Beta}(r)(N)$ & $\mathrm{BEF} \pm \mathrm{SD}(N)$ & $\operatorname{Beta}(r)(N)$ \\
\hline Alfalfa & $270 \pm 160(2)$ & $0.10(0.84)(11)$ & N.D. & & N.D. & \\
\hline Almond & $68 \pm 51(23)^{[24]}$ & $0.065(0.23)(157)^{*}$ & $150 \pm 28(6)^{[24]}$ & $0.16(0.90)(32)$ & $10000 \pm 3300(6)^{[24]}$ & $0.45(0.92)(31)$ \\
\hline Carrot (RL) & $78 \pm 45(15)^{[25]}$ & N.B. & $22 \pm 12(3)^{[25]}$ & $0.099(0.51)(11)$ & N.D. & \\
\hline Carrot $(\mathrm{BN})$ & $48 \pm 36(43)^{[27]}$ & $0.063(0.29)(166)^{*}$ & & & $56 \pm 36(3)^{[27]}$ & N.B. \\
\hline Cherry & $84 \pm 59(26)^{[26]}$ & $0.067(0.34)(121)^{*}$ & $670 \pm 250(16)^{[26]}$ & $0.30(0.94)(40)$ & N.D. & \\
\hline Corn & N.D. & & N.D. & & N.D. & \\
\hline Cotton Pima & $47 \pm 21(10)^{[27]}$ & $0.027(0.25)(31)^{*}$ & $2700 \pm 3100(5)$ & $0.13(0.35)(26)$ & N.D. & \\
\hline Cotton upland & $41 \pm 16(4)$ & $0.12(0.74)(16)$ & $81 \pm 83(4)$ & $0.18(0.26)(7)$ & N.D. & \\
\hline Table grape & $11 \pm 4.9(2)^{[28]}$ & N.B. & $26 \pm 13(5)$ & $0.029(0.27)(23)$ & $45 \pm 15(5)$ & $0.095(0.69)(13)$ \\
\hline Wine grape & $91 \pm 50(13)^{[27]}$ & $0.17(0.67)(20)$ & $44 \pm 10(3)^{[25]}$ & N.B. & $52 \pm 22(8)^{[27]}$ & N.B. \\
\hline Liquidambar & $350 \pm 260(31)^{[26]}$ & $0.098(0.35)(174)^{*}$ & $47 \pm 4.8(2)^{[26]}$ & $0.19(0.94)(4)$ & N.D. & \\
\hline Miscanthus & $140 \pm 89(17)^{[27]}$ & $0.044(0.20)(63)^{*}$ & $48 \pm 19(6)^{[28]}$ & $0.16(0.80)(11)$ & $180 \pm 31(6)^{[28]}$ & $0.076(0.76)(11)$ \\
\hline Olive & $60 \pm 32(8)^{[26]}$ & $0.15(0.68)(28)$ & $7.5 \pm 0.91(2)^{[26]}$ & $0.066(0.51)(4)$ & N.D. & \\
\hline Onion & $350 \pm 110(3)^{[28]}$ & N.B. & N.D. & & N.D. & \\
\hline Peach & $1200 \pm 270(2)^{[24]}$ & $0.23(0.97)(10)$ & $240 \pm 55(2)^{[24]}$ & $0.23(0.97)(10)$ & N.D. & \\
\hline Pistachio & $40 \pm 22(47)^{[28]}$ & $0.098(0.47)(207)^{*}$ & $39 \pm 55(15)^{[26]}$ & $0.15(0.36)(22)^{*}$ & N.D. & \\
\hline Plum & $37 \pm 20(5)^{[26]}$ & $0.010(0.04)(26)^{*}$ & $30 \pm 11(4)^{[28]}$ & $0.14(0.68)(6)$ & N.D. & \\
\hline Pomegranate & $32 \pm 26(4)^{[25]}$ & N.B. & $26 \pm 9.8(4)^{[27]}$ & $0.14(0.78)(5)$ & $61 \pm 8.6(5)^{[27]}$ & $0.024(0.23)(9)^{*}$ \\
\hline Potato & $150 \pm 9.8(3)^{[24]}$ & $0.064(0.47)(16)^{*}$ & $22 \pm 9.3(3)^{[27]}$ & N.B. & $40 \pm 13(3)$ & N.B. \\
\hline Tomato & $740 \pm 260(7)^{[27]}$ & $0.11(0.31)(68)^{*}$ & N.D. & & $59 \pm 15(3)^{[27]}$ & N.B. \\
\hline Orange P.N. (no flowers) & $2500 \pm 3400(116)^{[26]}$ & $0.14(0.35)(522)^{*}$ & $1300 \pm 1900(33)^{[26]}$ & N.B. & $1500 \pm 970(20)^{[25]}$ & $0.25(0.74)(58)$ \\
\hline Orange P.N. (flowers) & $7800 \pm 4300(36)^{[26]}$ & $0.15(0.71)(151)$ & $4600 \pm 1300(11)^{[24]}$ & $0.072(0.38)(36)^{*}$ & $3200 \pm 780(11)^{[24]}$ & $0.28(0.92)(36)$ \\
\hline Mandarin W. Murcott & $63 \pm 25(20)^{[28]}$ & $0.080(0.47)(99)^{*}$ & $150 \pm 190(8)^{[29]}$ & $0.23(0.79)(20)$ & N.D. & \\
\hline Mandarin clementine & $26 \pm 18(22)^{[26]}$ & $0.064(0.27)(141)^{*}$ & N.D. & & N.D. & \\
\hline Lemon Eureka & $22 \pm 22(24)^{[25]}$ & $0.036(0.15)(166)^{*}$ & N.M. & & N.M. & \\
\hline
\end{tabular}

Notes: N.M. stands for no measurements; N.D., below detection limit; N.A., no basal condition met; and N.B., beta value analysis inaccurate.
When the basal emission factor (BEF) was determined at a lower temperature and adjusted, the temperature it was determined at is indicated after the BEF as ${ }^{[C]}$, the value was adjusted using the calculated beta When the basal emission factor (BEF) was determined at a lower temperature and adjusted, the temperature it was determined at is indicated after the $\mathrm{BEF}$ as ${ }^{[C]}$, the value was adjusted using the calculated beta
unless the correlation coefficient for beta was below 0.5 , then a default beta of 0.1 was used and the beta column is marked with *.

The BEF sample size is the number of measurement samples used to determine the BEF, while the sample size in the beta column refers to the number of measurement samples where the compound classes were observed and used to calculate the beta value.

Data on citrus species measured in the same greenhouse campaign are reproduced from Fares et al. (2011) for comparison to the other crops and assessment of implications on air quality. Chemical speciation of emissions can be found in Tables S2-S5.

suggesting that higher emissions should be expected during harvesting.

Parent navel orange (P. N. orange) had a high monoterpene emission factor with a beta coefficient of 0.14 without flowers (temperature only algorithm), which is consistent with previous published work on oranges (Ciccioli et al., 1999). Emissions of total monoterpenes from other citrus species in

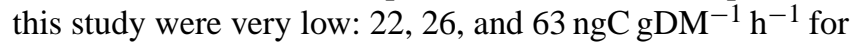
Eureka lemon, clementine mandarin, and W. Murcott mandarin, respectively. Monoterpene emissions from P. N. orange were predominantly $\beta$-myrcene and $\beta$-trans-ocimene, and mandarins emitted mainly $\beta$-cis- and $\beta$-trans-ocimene. Previous work has shown much higher emission for Lisbon lemons (Winer et al., 1992), which suggests potential variability in emissions owing to phenological factors.

Our emission measurements of pistachio are considerably lower than previous work classifying pistachio as a large monoterpene emitter; our BEF is more than 2 orders of magnitude lower than in Winer et al. (1992). Since pistachio acreage is very large in California, further studies on this crop are warranted as fundamental questions remain about pistachio's BEF. It is possible that although the same variety was used in both studies, specific phenotypic traits of the individuals selected could cause such differences. It is the case here with pistachio, as with many other crops surveyed in our study, that several replicates of a few individuals for a crop variety were likely inadequate to capture the variability in biogenic emissions within individuals of the same species, between different crops, and during different periods of an individual's life or annual cycle. The results of this portion of the study are also subject to the limitations of the greenhouse environment, compared to the field; plants were potted and were exposed to lower than typical light and temperature conditions. Thus, it is important to note that the results presented from the greenhouse study comprise a survey of emissions from a broad suite of crops, and more extensive measurements are critical to effectively characterize emissions from a particular crop species. Future users of these individual crop data should be cautious of the variability between individuals of the same species and their seasonal cycles.

\subsubsection{Oxygenated monoterpenes}

Oxygenated monoterpene emissions from crops have not been reported extensively in the past. The most prevalent oxygenated monoterpene observed in the greenhouse study was perillene. Emissions of oxygenated monoterpenes were highest from flowering orange 
$\left(\mathrm{BEF}=4600 \mathrm{ngC} \mathrm{gDM}^{-1} \mathrm{~h}^{-1}\right)$, followed by Pima cotton and non-flowering orange (2700 and $1300 \mathrm{ngC} \mathrm{gDM}^{-1} \mathrm{~h}^{-1}$, respectively). Lower emissions were observed from cherry, peach, almond, and W. Murcott mandarin, with very low emissions from the other crops (Table 2). Modeled and measured emissions of oxygenated monoterpenes from non-flowering orange trees were not well correlated. The occurrence of perillene may suggest that neither of the modeling methods represents emissions of this furanoid. For flowering oranges, the temperature only method best describes the emission of oxygenated monoterpenes, mainly linalool, confirming the temperature dependency of linalool emissions reported previously (Ciccioli et al., 1999).

\subsubsection{Sesquiterpenes}

Almond was the highest sesquiterpene emitter of the crops studied according to the calculated BEF $\left(10000 \mathrm{ngCgDM}^{-1} \mathrm{~h}^{-1}\right)$, while the magnitude of the monoterpene and oxygenated monoterpene emissions was very low. This sesquiterpene BEF was anomalous, so we report it with low confidence. The calculated beta of 0.45 is very high, and all the measurements for almond were below $25^{\circ} \mathrm{C}$. Using a beta of 0.1 , the BEF would be 1200 (a factor of 10 lower, but still a significant emission). Sesquiterpene emissions were very low or not detected for other non-citrus woody crops. Sesquiterpene emissions from tomato were $59 \mathrm{ngC} \mathrm{gDM}^{-1} \mathrm{~h}^{-1}$, slightly lower than the range reported in previous work for different varietals (Winer et al., 1992). After almond trees, P. N. orange trees had the highest sesquiterpene emission rates, with the flowering specimen being twice that of the non-flowering trees.

\subsection{Emissions from flowering citrus trees}

Many trees and herbaceous plants produce flowers once or more every year. In the greenhouse enclosure studies, flowering increased monoterpene emissions from orange trees by a factor of 3 with only a few flowers (a lower density than observations at the field site). The presence of flowers has been shown previously to dramatically influence the magnitude and composition of emissions from orange trees (Ciccioli et al., 1999; Hansen et al., 2003; Arey et al., 1991a). In the greenhouse study $\beta$-myrcene and $\beta$-trans-ocimene were the dominant monoterpenes emitted from orange trees (Table S3). $\beta$-cis-ocimene was also observed from the flowering plants. Emissions of the oxygenated monoterpene linalool increased by a factor of $\sim 3.5$ from the flowering plant. $\beta$ caryophyllene emissions also increased by a factor of 2 for the flowering orange tree. Increased emissions from the flowering orange tree were observed for all compounds measured (Fares et al., 2011), but the other Citrus species had no flowering individuals for comparison.

During the spring field measurement campaign at the orange orchard, a broad array of biogenic gas-phase organic

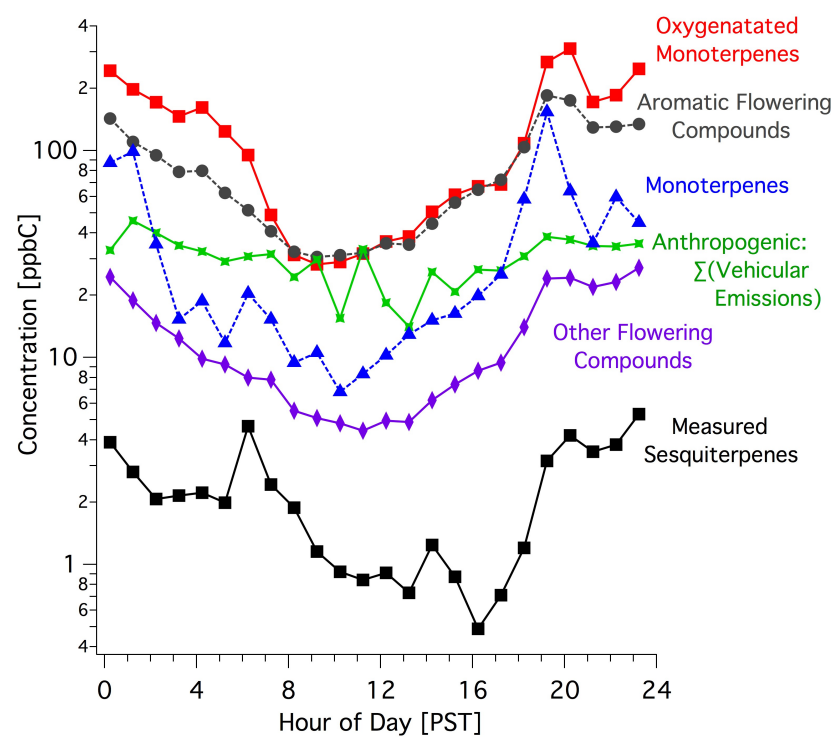

Figure 1. Average diurnal patterns of different compound classes shown on a logarithmic scale during flowering at the Lindcove site. Anthropogenic emissions from motor vehicles are shown for comparison. Floral emissions of oxygenated monoterpenes and aromatics dominate total biogenic emissions. Measured sesquiterpenes are lower than total sesquiterpenes as not all sesquiterpenes could be observed/quantified.

compounds was measured in ambient air (Table 3). Flowering occurring at the field site, and in the local area, had a major impact on the distribution of biogenic compounds in ambient air. There was a dramatic increase in both the magnitude and diversity of chemical species emitted during the flowering process. Due to strong nocturnal inversions, many were measured at ppb-level concentrations at night owing to their buildup in the shallow boundary layer where ozone had been scavenged to concentrations below $10 \mathrm{ppb}$. Perhaps of more interest is that daytime concentrations averaged above $10 \mathrm{ppt}$ for most compounds, when their emissions are most relevant to photochemistry. Additionally, several of the most prominent compounds had daytime concentrations that regularly exceeded $1 \mathrm{ppb}$ (Table 3 ).

$\beta$-myrcene was the principal monoterpene observed during flowering, while linalool was overall the most abundant terpenoid compound observed. However, there were high concentrations of a wide variety of compounds during the flowering period that had strong diurnal patterns (Fig. 1). While many of the biogenic compounds observed at the site were terpenoids, there was a diverse array of functionalized aromatic compounds that were clearly biogenic and associated with flowering (Tables 3-5). This was evidenced by their strong correlations to $\beta$-myrcene and linalool (Tables 5-6), which are known from the greenhouse and field site measurements to be associated with flowering. To our knowledge, several of the compounds observed and measured have 
Table 3. Interquartile ranges [pptv] for measured biogenic compounds in spring and summer.

\begin{tabular}{|c|c|c|c|c|}
\hline \multirow[b]{2}{*}{ Compound } & \multicolumn{2}{|c|}{ Spring (flowering) } & \multicolumn{2}{|c|}{ Summer } \\
\hline & $\begin{array}{l}\text { Day } \\
(10: 00-17: 00)\end{array}$ & $\begin{array}{l}\text { Night } \\
(20: 00-06: 00)\end{array}$ & $\begin{array}{l}\text { Day } \\
(10: 00-17: 00)\end{array}$ & $\begin{array}{l}\text { Night } \\
(20: 00-06: 00)\end{array}$ \\
\hline isoprene & $24.8-67.4$ & $55.5-375.8$ & $61.3-197.8$ & $107.4-852.8$ \\
\hline$\alpha$-thujene & $3.8-13.7$ & $16.4-122.0$ & $2.5-3.7$ & $4.6-19.1$ \\
\hline$\alpha$-pinene & $6.9-13.0$ & $12.6-90.8$ & $3.2-6.8$ & $5.4-20.7$ \\
\hline camphene & $4.4-6.8$ & $6.2-40.2$ & $3.7-7.7$ & $7.0-26.5$ \\
\hline sabinene & $23.6-67.6$ & $62.7-977.5$ & $11.5-23.2$ & $15.7-33.7$ \\
\hline$\beta$-myrcene & $324.1-1143.2$ & $407.9-2285.4$ & $4.4-9.3$ & $8.4-49.8$ \\
\hline$\beta$-pinene & BDL-17.7 & $12.8-52.3$ & & \\
\hline$\alpha$-phellandrene & $1.3-3.1$ & $2.1-5.1$ & $2.3-6.7$ & $7.0-35.1$ \\
\hline cis-3-hexenyl acetate & $165.3-353.7$ & 213.3-790.2 & & \\
\hline$\Delta 3$-carene & $23.0-51.1$ & $37.0-162.0$ & $3.2-5.2$ & $5.2-38.5$ \\
\hline Benzaldehyde & $69.5-276.0$ & $78.6-434.3$ & & \\
\hline$\alpha$-terpinene & $5.3-12.0$ & $12.0-102.1$ & & \\
\hline cis- $\beta$-ocimene & $23.9-65.9$ & $39.5-162.5$ & & \\
\hline trans- $\beta$-ocimene & $134.8-380.3$ & $197.6-1267.1$ & & \\
\hline$\Delta$-limonene & $183.6-365.0$ & $275.2-2250.5$ & $158.9-271.9$ & $204.1-1606.0$ \\
\hline$p$-cymene & $17.8-41.1$ & $26.0-238.6$ & $7.8-16.6$ & $16.4-176.5$ \\
\hline$\gamma$-valeroactone & $6.2-11.3$ & $11.2-103.3$ & & \\
\hline$\gamma$-terpinene & $16.4-32.4$ & $30.6-247.6$ & $1.6-7.5$ & $4.1-15.5$ \\
\hline terpinolene & $6.7-15.6$ & $14.2-85.8$ & $1.7-2.7$ & $6.8-22.2$ \\
\hline trans-linalool oxide & $1.7-5.1$ & $3.3-18.0$ & & \\
\hline cis-linalool oxide & $9.2-14.9$ & $11.6-50.6$ & & \\
\hline benzeneacetaldehyde & $57.1-242.4$ & $86.8-455.7$ & & \\
\hline linalool & $1657.3-6037.5$ & 2436.4-18342.1 & & \\
\hline lavender lactone & $122.5-278.6$ & 216.3-1033.1 & & \\
\hline sabina ketone & $16.8-111.9$ & $58.8-255.1$ & & \\
\hline 2-amino-benzaldehyde & $174.0-443.1$ & $189.2-806.2$ & & \\
\hline indole & $984.6-2707.4$ & $1408.4-3696.6$ & & \\
\hline methyl anthranilate & $906.6-2742.4$ & $1151.8-6856.5$ & & \\
\hline benzeneethanol & $188.2-420.4$ & $215.8-966.7$ & & \\
\hline benzyl nitrile & $836.6-1780.8$ & $971.7-3212.2$ & & \\
\hline methyl benzoate & $14.9-32.8$ & $19.8-57.6$ & & \\
\hline$\beta$-caryophyllene & $9.7-19.6$ & $7.0-18.4$ & & \\
\hline aromadendrene & $7.2-25.0$ & $10.2-31.9$ & & \\
\hline trans- $\beta$-farnesene & $3.1-21.5$ & $6.9-41.7$ & & \\
\hline valencene & BDL-17.1 & $13.3-59.2$ & & \\
\hline trans-Nerolidol & $22.7-150.9$ & $64.0-301.1$ & & \\
\hline$n$-pentadecane & $12.6-29.5$ & $14.6-35.8$ & & \\
\hline$n$-hexadecane & $8.1-37.3$ & $5.4-34.9$ & & \\
\hline$n$-heptadecane & $36.6-83.7$ & $38.7-101.4$ & & \\
\hline 8-heptadecene & $1.2-7.1$ & $2.0-52.0$ & & \\
\hline 1-heptadecene & 79.0-204.3 & $105.5-285.5$ & & \\
\hline hexanal & $35.8-162.7$ & $81.0-337.8$ & & \\
\hline octanal & $11.6-25.3$ & $17.3-73.9$ & & \\
\hline nonanal & $55.0-120.4$ & $68.6-184.2$ & & \\
\hline decanal & $6.9-21.1$ & $11.3-40.1$ & & \\
\hline
\end{tabular}

Notes: entries left blank indicate that compound was not observed during the summer campaign (sesquiterpenes could not be measured during the summer due to chromatographic and detector difficulties).

BDL: below detection limit. 
Table 4. Novel compounds from measurements of ambient air during flowering.

\begin{tabular}{|c|c|c|c|}
\hline Name(s) & Structure & $\begin{array}{c}\mathrm{k}_{\mathrm{OH}}\left[\mathrm{cm}^{3} \mathrm{~s}^{-1}\right. \\
\text { molecules } \\
\end{array}$ & $\begin{array}{l}\text { Lifetime to } \mathrm{OH} \\
\text { oxidation [min] }\end{array}$ \\
\hline Indole & & 15.4 & 20 \\
\hline $\begin{array}{l}\text { Methyl Anthranilate (benzoic } \\
\text { acid, 2-amino-, methyl ester) }\end{array}$ & & 3.48 & 89 \\
\hline $\begin{array}{l}\text { Benzeneacetaldehyde } \\
\text { (phenyl acetaldehyde) }\end{array}$ & & 2.63 & 117 \\
\hline $\begin{array}{l}\text { Benzeneethanol } \\
\text { (phenylethyl alcohol) }\end{array}$ & & 0.957 & 323 \\
\hline $\begin{array}{l}\text { Benzyl Nitrile } \\
\text { (benzneacetonitrile) }\end{array}$ & & 0.962 & 321 \\
\hline $\begin{array}{l}\text { Lavender Lactone ( } \gamma \text {-lactone, } \\
\text { dihydro-5-methyl-5-vinyl- } \\
2(3 \mathrm{H}) \text {-furanone })\end{array}$ & & 2.76 & 112 \\
\hline $\begin{array}{l}\text { Methyl Benzoate } \\
\text { (Methyl Benzenecarboxylate, } \\
\text { Niobe Oil) }\end{array}$ & & 0.0844 & 3660 \\
\hline $\begin{array}{l}\text { Sabina Ketone } \\
\text { (5-isopropylbicyclo } \\
\text { [3.1.0]hexan-2-one) }\end{array}$ & & 0.626 & 493 \\
\hline 2-amino-benzaldehyde & & 5.23 & 59 \\
\hline
\end{tabular}

not been previously reported in other studies of ambient air. These compounds were initially identified through highquality matches to mass spectra libraries and Kovat's indices for appropriate retention times, and then later confirmed with authentic standards after the campaign. Table 4 summarizes their chemical structures and reactivity. Many of the compounds we observed during flowering have been attributed to floral scents or essential oils from flowers in various botany and ecology studies, which include a variety of compounds with aromatic rings, as well as nitrogen, sulfur, and/or oxygen-containing functional groups (Lewis et al., 2007; Afsharypuor and Jamali, 2006; Bendimerad et al.,
2007; Bernhardt et al., 2003; Azuma et al., 2001; Omura et al., 1999; Kotze et al., 2010).

Given the novelty of the measurements for these compounds, no previous work validates the efficacy of measurement methods or interactions with ozone removal traps at the inlet. While additional measurement uncertainty is warranted, we are confident in the methods used for these compounds as we were able to accurately measure other compounds in their volatility range $\left(\mathrm{C}_{11-15}\right)$ and greater in this study and Gentner et al. (2012). Also, the ozone traps used in this work were evaluated by Pollmann et al. (2005) and shown to be acceptable for the sesquiterpenes tested, which are less volatile and more reactive, albeit less 
Table 5. Compounds well-correlated with flowering emissions (represented by $\beta$-myrcene).

\begin{tabular}{lccc}
\hline Compound & $\mathrm{mol} \mathrm{mol}^{-1} \beta$-myrcene & \pm Std. dev. & Correlation coeff. $(r)$ \\
\hline linalool & 7.1 & 0.2 & 0.92 \\
methyl anthranilate & 1.2 & 0.04 & 0.95 \\
indole & 0.62 & 0.02 & 0.93 \\
benzyl nitrile & 0.38 & 0.03 & 0.78 \\
$\Delta$-limonene & 0.35 & 0.03 & 0.73 \\
trans- $\beta$-ocimene & 0.31 & 0.01 & 0.93 \\
benzeneacetaldehyde & 0.26 & 0.02 & 0.76 \\
2-amino-benzaldehyde & 0.23 & 0.007 & 0.95 \\
benzeneethanol & 0.22 & 0.007 & 0.94 \\
lavender lactone & 0.18 & 0.01 & 0.78 \\
cis-3-hexenyl acetate & 0.15 & 0.006 & 0.93 \\
benzaldehyde & 0.081 & 0.006 & 0.78 \\
1-heptadecene & 0.040 & 0.002 & 0.91 \\
cis- $\beta$-ocimene & 0.025 & 0.002 & 0.79 \\
$\Delta 3$-carene & 0.023 & 0.002 & 0.79 \\
cis-linalool oxide & 0.015 & 0.0005 & 0.93 \\
octanal & 0.014 & 0.0009 & 0.82 \\
$n$-heptadecane & 0.011 & 0.0006 & 0.85 \\
terpinolene & 0.0096 & 0.0009 & 0.70 \\
methyl benzoate & 0.0071 & 0.0006 & 0.75 \\
valencene & 0.0067 & 0.0005 & 0.83 \\
decanal & 0.0060 & 0.0006 & 0.71 \\
aromadendrene & 0.0048 & 0.0002 & 0.88 \\
$n$-pentadecane & 0.0041 & 0.0002 & 0.91 \\
trans-linalool oxide & 0.0032 & 0.0003 & 0.76 \\
$\beta$-caryophyllene & 0.0030 & 0.0002 & 0.83 \\
\hline
\end{tabular}

functionalized than the chemical species reported here. Nevertheless, the measurements we report are potentially lower limits in the event of chemical or physical losses in our sampling/measurement system.

There were several previously unidentified peaks observed during measurements of the flowering P. N. orange in the greenhouse studies that have very good retention time matches to these flowering compounds measured at this site, including indole, methyl anthranilate, benzeneethanol, benzyl nitrile, 2-aminobenzaldehyde, and possibly sabina ketone (Fig. S2). In the greenhouse measurements, these compounds were observed only from the flowering specimen, supporting the conclusion that flowering is the source. At the field site, daytime concentrations of methyl anthranilate, indole, and benzyl nitrile were over $1 \mathrm{ppb}$, similar or greater than the dominant monoterpene $\beta$-myrcene. Lavender lactone, benzeneethanol, 2-amino-benzaldehyde, and benzeneacetaldehyde had significant median daytime concentrations at, or above, 100 ppt. Sabina ketone and methyl benzoate had lower concentrations similar to the linalool oxide isomers, but still appeared to be emitted in significant amounts. cis-3-Hexenyl acetate, a well-known plant-wounding compound (Fall et al., 1999), had considerable nighttime concentrations ranging 200-800 ppt despite no harvest or pruning activity, and correlated well with other flowering compounds, suggesting that it is also released as part of the flowering process. In addition to these compounds, we also observed several high-molecularweight straight alkanes and alkenes associated with flowering (e.g., $n$-heptadecane, 1-heptadecene), which have been reported in other floral and essential oil analyses (Lewis et al., 2007; Afsharypuor and Jamali, 2006; Bendimerad et al., 2007; Bernhardt et al., 2003; Kotze et al., 2010; Winer et al., 1992). Additionally, emissions of benzyl alcohol and benzaldehyde were recently observed in a flowering tree enclosure study (Baghi et al., 2012). At our field site, the diurnal patterns of the flowering-related compounds were similar to that of monoterpenes, but were more prevalent (Figs. 12). A regression of the flowering-related compounds to the sum of monoterpenes yielded a ratio of 4.0 (on a carbon mass basis), with the sum of monoterpenes also including compounds that were related to flowering (i.e., $\beta$-myrcene, sabinene, and both $\beta$-ocimenes).

There were several sesquiterpenes observed at the site during flowering, several of which we were not able to identify, but the concentrations measured were considerably lower than many of the other terpenoids. The dominant observed sesquiterpenes were $\beta$-caryophyllene, aromadendrene, trans- $\beta$-farnesene, valencene, and trans-nerolidol (all confirmed with standards). Given the high reactivity of sesquiterpenes, the lower magnitude of concentrations does 


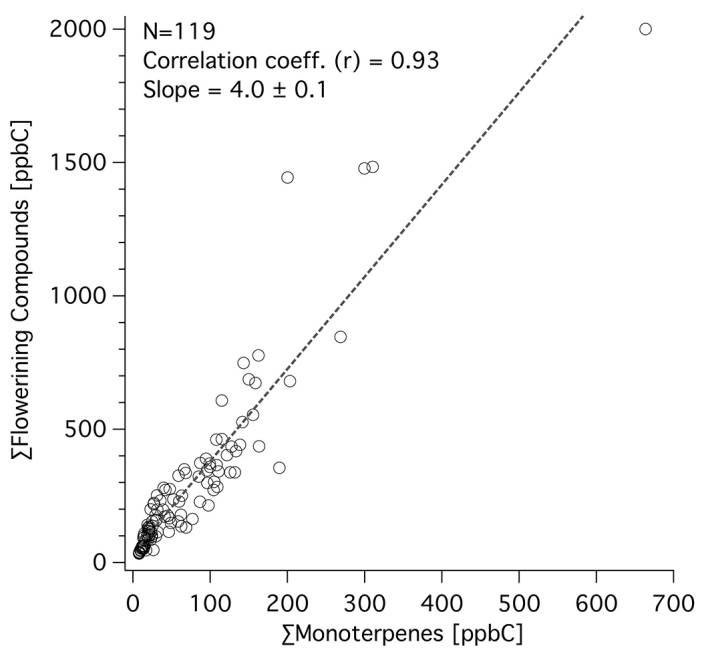

Figure 2. Comparison of total observed flowering compounds to the sum of monoterpenes during the spring at the Lindcove site. Concentrations were well correlated with a slope of 4.0, but can be expected to vary somewhat with the density of blossoms over the whole period of flowering. In addition to the flowering countdowns, large increases in monoterpenes concentrations were observed.

not necessarily imply lower emissions, but could also be a result of sesquiterpene compounds reacting at more rapid rates in the atmosphere than other terpenoid compounds. Sampling methodology can sometimes be responsible for underestimates of ambient concentrations, but the sampling and measurement techniques used in this study are suitable for sesquiterpene measurements (Bouvier-Brown et al., 2009; Pollmann et al., 2005). It is very likely that only a fraction of the emitted sesquiterpenes were measured due to their short atmospheric lifetimes, reacting with both $\mathrm{OH}$ and ozone.

We were only able to detect and identify a few sesquiterpenes. However, previous work (Ormeno et al., 2010) has shown that a wide array of sesquiterpenes are emitted from agricultural crops (flowering and non-flowering) and that emissions of sesquiterpenes should be roughly equivalent to those of monoterpenes. In the spring, measured sesquiterpenes were on average $5 \%$ of monoterpenes by carbon mass, but flowering is an episodic event and is not representative of an annual average. Previous work with the MEGAN model estimates sesquiterpene emission to be $9-16 \%$ of monoterpenes, but sesquiterpene data for input into the MEGAN model is limited (Sakulyanontvittaya et al., 2008). Figure 3 shows the relative amounts of sesquiterpenes to monoterpenes. It is evident that there is a dynamic range of observed ratios that varies over the course of the day and it is quite possible that additional, unaccounted for sesquiterpenes will increase the ratio.

The concentrations of sesquiterpenes during flowering were higher than previous work done in a ponderosa pine forest, where concentrations of individual sesquiterpenes were on the order of $10 \mathrm{ppt}$ (Bouvier-Brown et al., 2009), but
Table 6. Source profile ( \pm Std. Dev.) for flowering emissions (nonmonoterpene) from citrus trees.

\begin{tabular}{lc}
\hline Compound & $\%$ mass \\
\hline linalool & $70.4 \pm 2.8 \%$ \\
methyl anthranilate & $12.1 \pm 0.5 \%$ \\
indole & $4.65 \pm 0.19 \%$ \\
benzyl nitrile & $2.86 \pm 0.21 \%$ \\
benzeneacetaldehyde & $2.02 \pm 0.16 \%$ \\
2-amino-benzaldehyde & $1.79 \pm 0.07 \%$ \\
benzeneethanol & $1.75 \pm 0.07 \%$ \\
lavender lactone & $1.48 \pm 0.12 \%$ \\
cis-3-hexenyl acetate & $1.38 \pm 0.06 \%$ \\
1-heptadecene & $0.61 \pm 0.03 \%$ \\
benzaldehyde & $0.55 \pm 0.04 \%$ \\
$n$-heptadecane & $0.16 \pm 0.01 \%$ \\
cis-linalool oxide & $0.16 \pm 0.01 \%$ \\
methyl benzoate & $0.06 \pm 0.01 \%$ \\
trans-linalool oxide & $0.03 \pm 0.003 \%$ \\
\hline
\end{tabular}

Note: the monoterpenes $\beta$-myrcene and trans- $\beta$-ocimene are also observed in large concentrations during flowering and can be expected as part of the source profile (relative ratios can be calculated from Table 5).

there are very few published ambient air measurements of sesquiterpenes with which to compare our observations. Our summertime measurements did not have the capacity to measure sesquiterpenes due to chromatographic and detector difficulties.

\subsection{Seasonal differences in biogenic emissions}

While there were considerable year-round concentrations of monoterpenes at the site, there was a strong increase in biogenic emissions during the flowering period. A comparison indicates that the daytime sum of monoterpenes during spring flowering was $6 \pm 1$ times those in summer nonflowering conditions (Figs. 4-5)(10-16 PST prior to large changes in friction velocity in the late afternoon (Fares et al., 2012b)). The diurnal pattern of monoterpenes between the two seasons was similar, despite higher concentrations in the spring during flowering (Fig. 4). Given the similarities between $\Delta$-limonene during the two seasons, the difference can be attributed to the other monoterpenes associated with flowering. Over the summer, $\Delta$-limonene was the predominant monoterpene, but during flowering, $\beta$-myrcene, sabinene, and trans- $\beta$-ocimene were equally prevalent (Fig. 4, Table 7). A variety of other monoterpenes were present during both seasons, but made up relatively minor fractions.

While we measured fewer biogenic compounds during the summer campaign relative to the spring, we still observed a variety of monoterpenes in ambient air. We did not observe most of the compounds that were associated with flowering, including many of the oxygenated monoterpenes and benzenoids. There were similar diurnal patterns in the summer compared to the spring due predominantly to boundary 

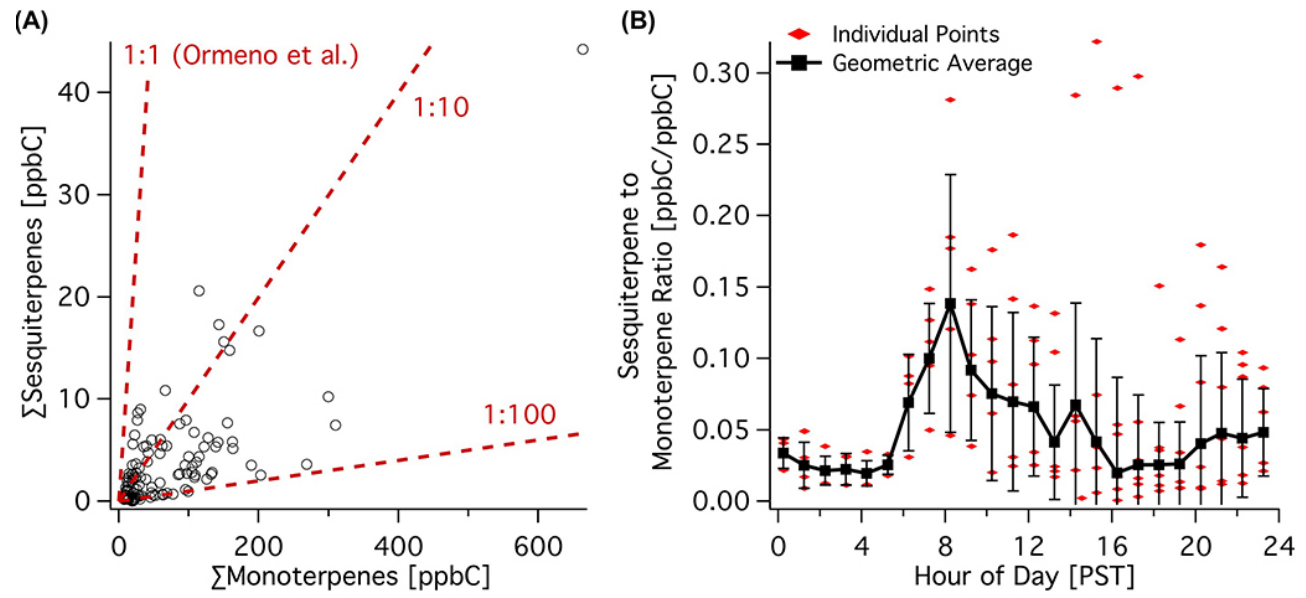

Figure 3. (A) The comparison of quantified sesquiterpenes to monoterpenes during the spring at Lindcove shows considerable variance in their ratio to each other. The 1:1 ratio expected by Ormeno et al. (2010) is shown, but is not reached due to measurements of a partial suite of sesquiterpenes and their greater atmospheric reactivity. (B) The diurnal pattern of sesquiterpenes to monoterpenes shows a higher ratio during the day than at night. Ratios are the highest early in the morning possibly due to lower levels of atmospheric oxidants $\left(\mathrm{OH}_{\text {and }} \mathrm{O}_{3}\right)$ in the morning and the presence of fresh emissions accumulating after sunrise in a shallow boundary layer.
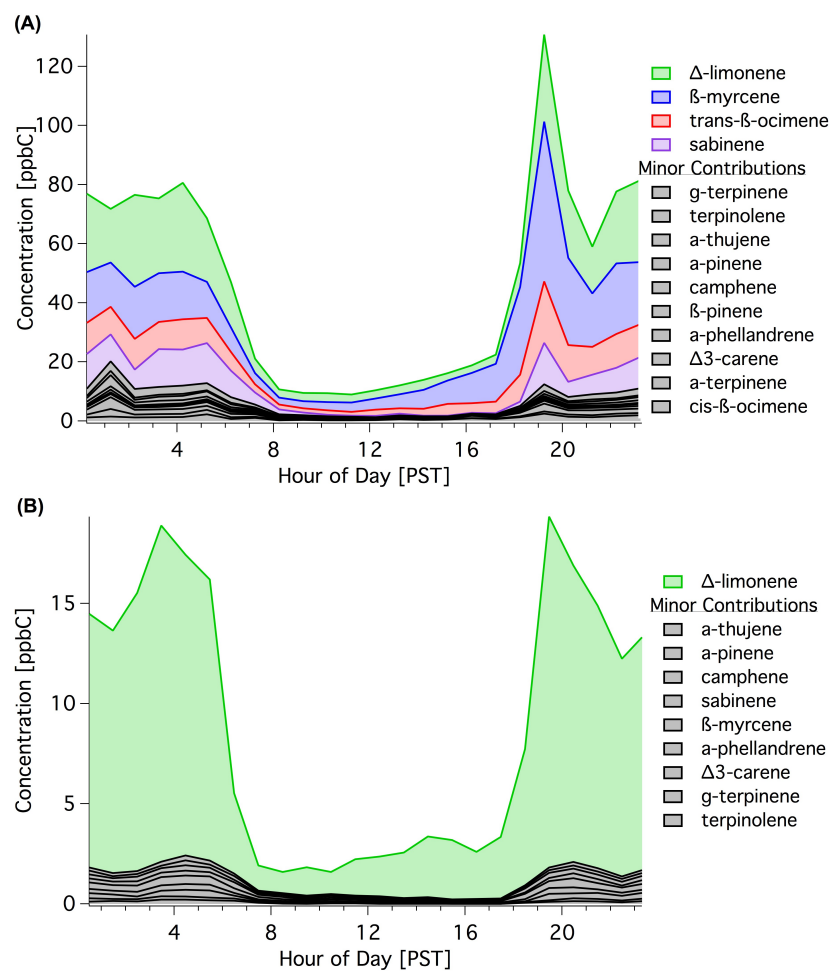

Figure 4. Diurnal pattern and composition of monoterpenes in (A) spring during flowering and in (B) summer.

layer effects and reaction with atmospheric oxidants. At night in both seasons, ozone concentrations were below $10 \mathrm{ppb}$ due to stomatal deposition and reaction with biogenic VOCs and NO (Fares et al., 2012b). The concentration minima of limonene and $p$-cymene occurred during the day with sta-
Table 7. Summary of monoterpene composition for both seasonal campaigns at Lindcove.

\begin{tabular}{lcc}
\hline Compound & Spring (flowering) & Summer \\
\hline$\beta$-myrcene & $34.2 \%$ & $2.4 \%$ \\
sabinene & $12.8 \%$ & $2.2 \%$ \\
$\Delta$-limonene & $24.2 \%$ & $87.6 \%$ \\
$\gamma$-terpinene & $2.0 \%$ & $1.0 \%$ \\
cis- $\beta$-ocimene & $2.9 \%$ & - \\
trans- $\beta$-ocimene & $13.6 \%$ & - \\
$\alpha$-thujene & $1.7 \%$ & $1.1 \%$ \\
$\Delta 3$-carene & $3.7 \%$ & $1.3 \%$ \\
$\alpha$-pinene & $0.7 \%$ & $0.80 \%$ \\
$\alpha$-terpinene & $0.77 \%$ & - \\
$\alpha$-phellandrene & $0.93 \%$ & $1.3 \%$ \\
terpinolene & $0.84 \%$ & $0.7 \%$ \\
$\beta$-pinene & $0.91 \%$ & $2.60 \%$ \\
camphene & $0.70 \%$ & $1.6 \%$ \\
\hline
\end{tabular}

tistically equivalent concentrations between the two seasons. This similarity is likely a combination of slight changes in emissions, photochemical processing via $\mathrm{OH}$, and meteorological dilution.

The chemical speciation of monoterpenes is summarized in Table 7. There is a similar distribution and diversity of monoterpenes between the two seasons, with the exception of $\beta$-myrcene, sabinene, and trans- $\beta$-ocimene, which increased significantly with flowering. Concentrations of total monoterpenes during the summer were similar to those observed at a California ponderosa pine forest in warm temperatures $\left(26^{\circ} \mathrm{C}\right.$ daytime mean), but the distribution of monoterpenes was significantly different; there was much more $\Delta$ limonene and less $\alpha$ - and $\beta$-pinene compared to the pine 

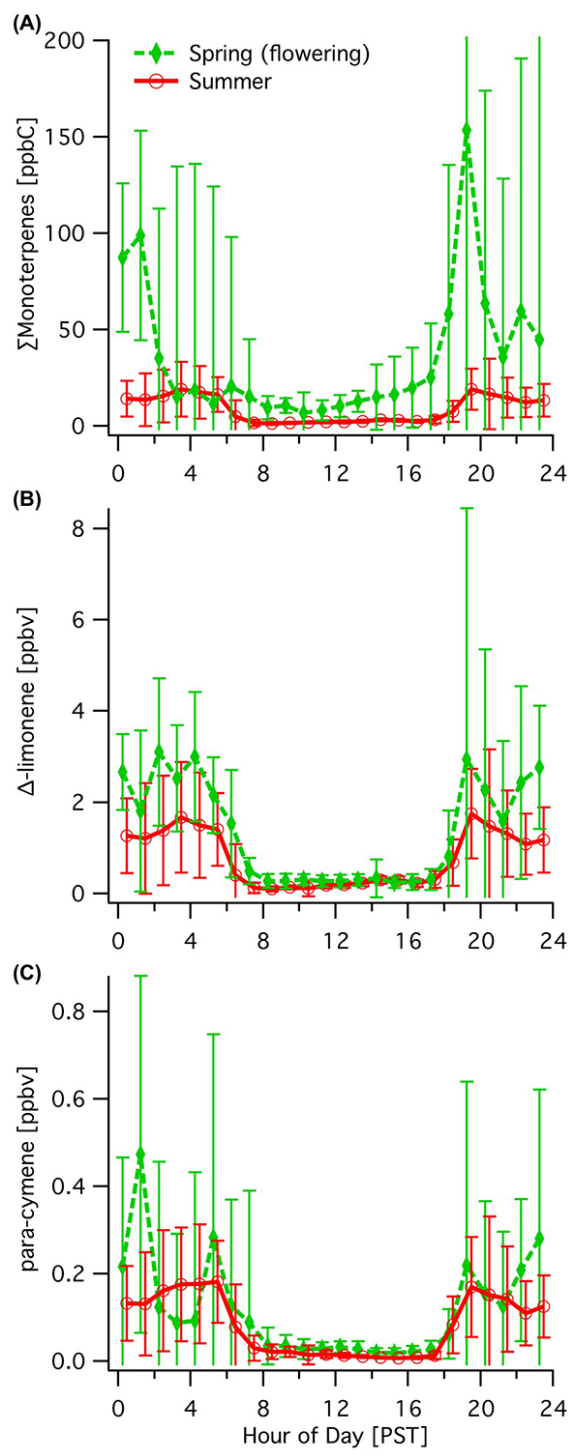

Figure 5. Seasonal comparison of diurnal concentration patterns for (A) total monoterpenes, (B) $\Delta$-limonene, and (C) $p$-cymene, shown with standard deviations. The seasonal comparison of $\Delta$-limonene and $p$-cymene concentrations demonstrates similar seasonal abundances that are slightly higher during flowering.

forest (Bouvier-Brown et al., 2009). $\Delta$-limonene was the most prevalent monoterpene observed in the summer and its diurnal patterns and interquartile concentrations were similar but slightly higher in the spring (Fig. 5b, Table 3). $p$ Cymene is a known aromatic emitted from (non-flowering) plants with a wide variety of sources and a few minor anthropogenic sources (e.g., gasoline). Similar to $\Delta$-limonene, Fig. 5c shows that it was similar between the two seasons both in prevalence and diurnal pattern. The potential anthropogenic contribution to $p$-cymene is negligible given the relatively low concentrations of dominant gasoline tracers. The relatively comparable concentrations of several monoter- penes during the two measurement periods in the orange orchard imply similar emission rates during those two periods.

\subsection{Transport of biogenic emissions in the San Joaquin Valley}

The relative magnitude of biogenic versus anthropogenic emissions and compound concentrations vary depending on location in the San Joaquin Valley as shown by the comparison of the Bakersfield and Lindcove sites (Fig. 6). Given the geographic distribution of agriculture and urban areas in the San Joaquin Valley, the transport of biogenic emissions from more vegetated areas is important, and can affect atmospheric reactivity and secondary pollutant formation throughout the valley (Rollins et al., 2012; Shilling et al., 2013).

We devised a technique to demonstrate the transport and photochemical processing of primary biogenic emissions in the San Joaquin Valley using the dynamic behavior of several pairs of monoterpenes measured in Bakersfield at the southern end of the valley. We compared their ratios over $\sim 700$ samples to examine the importance of aging by the three primary atmospheric oxidants $\left(\mathrm{OH}, \mathrm{O}_{3}, \mathrm{NO}_{3}\right)$. Each monoterpene measured at Bakersfield reacts at different rates with each oxidant, and so by picking monoterpene pairs appropriately, we determined the most important oxidants for aging and their timescales (e.g., lifetime $=1 /\left(k_{\mathrm{OH}}[\mathrm{OH}]\right)$ ).

A comparison of $\Delta$-limonene to $\alpha$-pinene shows a distribution of ratios (Fig. 7). While some of this variability is possibly due to differences in emissions, it is evident that aging is playing an important role in the variability of observed ratios. $\Delta$-limonene reacts faster than $\alpha$-pinene with all three atmospheric oxidants, but given the average concentrations of the oxidants, $\mathrm{OH}$ oxidation is the fastest and will have the strongest influence on the observed ratios. We used $24 \mathrm{~h}$ oxidant average concentrations of $0.25 \mathrm{pptv}, 41 \mathrm{ppbv}$, and 0.29 pptv for $\mathrm{OH}, \mathrm{O}_{3}$, and $\mathrm{NO}_{3}$, respectively, at the Bakersfield site based on observations (with steady-state calculations for $\mathrm{NO}_{3}$ ) and literature values (Bouvier-Brown et al., 2009; Brown et al., 2009; Rollins et al., 2012). A comparison of $\Delta$-limonene to $p$-cymene (Fig. S3) similarly demonstrates the importance of aging by $\mathrm{OH}$ as the differences in reaction rates are more pronounced than between $\Delta$-limonene and $\alpha$ pinene.

A similar comparison of camphene to $\alpha$-pinene suggests a constant initial emission ratio from regional sources and infers less pronounced aging by ozone and nitrate radicals (Fig. 7b). The observed variability is less dramatic than the other monoterpene pairs and likely due to $\mathrm{O}_{3}$ and $\mathrm{NO}_{3}$, given that $\mathrm{OH}$ reaction rates are identical. Overall, this analysis indicates the presence of these oxidation mechanisms and shows the predominance of $\mathrm{OH}$ oxidation. Although the degree of oxidation is dependent on the timescales and diurnal patterns of biogenic compounds arriving to Bakersfield. Overall, our findings are consistent with recent work 

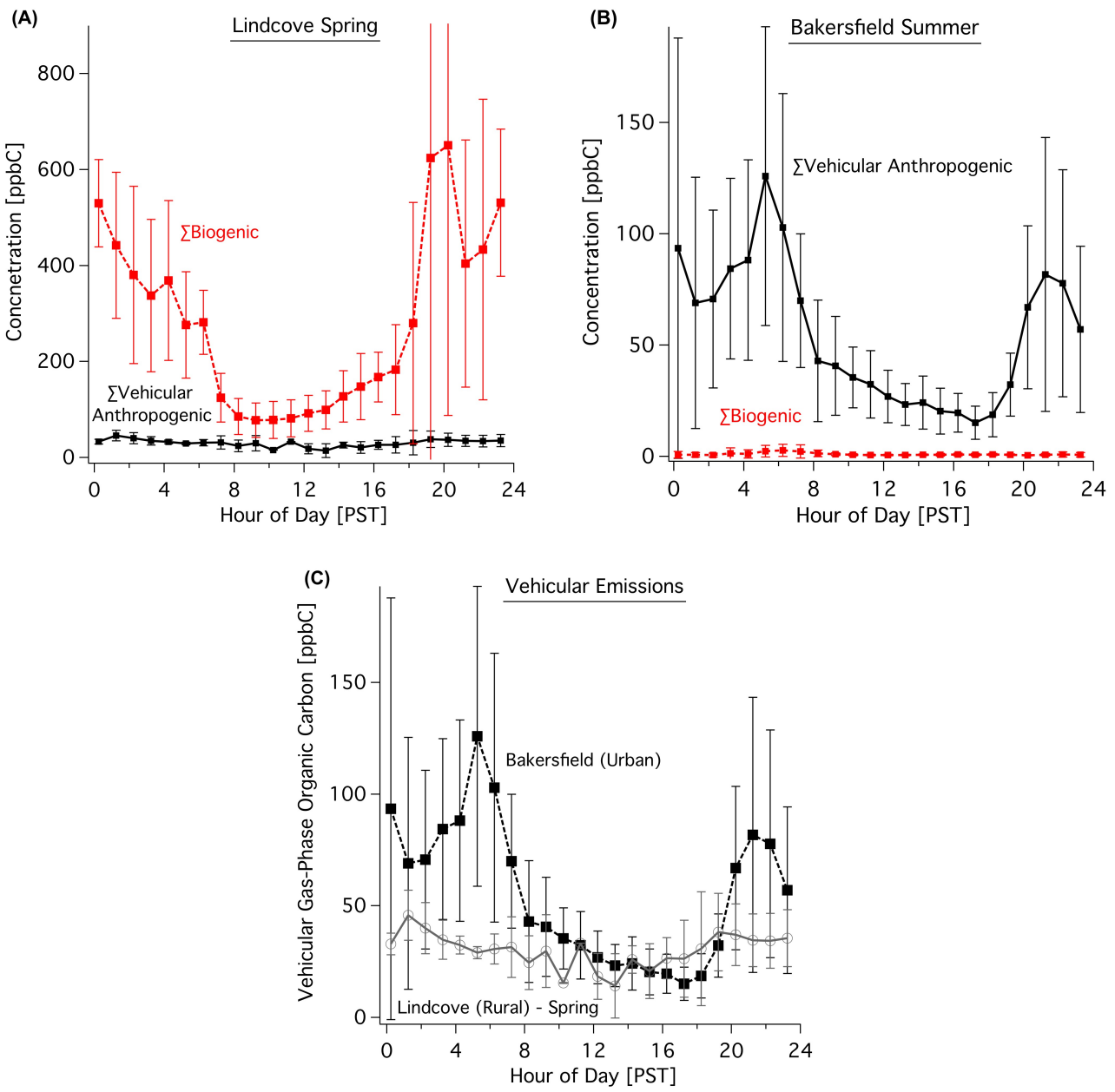

Figure 6. Diurnal patterns of the sum of biogenic compounds predominantly from agriculture (larger than isoprene) vs. anthropogenic compounds from motor vehicles (including emissions from service stations) at the (A) Lindcove orange orchard site in the spring and (B) the urban Bakersfield site (biogenic compounds are largely monoterpenes). (C) A comparison of motor vehicle compound concentrations between the Bakersfield and Lindcove site shows similar daytime levels, but nighttime and morning values vary due to the buildup of local emissions in the nocturnal boundary layer.

reporting the presence of nitrate chemistry and also a study showing the dominance of $\mathrm{OH}$ oxidation of biogenic compounds (Rollins et al., 2012; Donahue et al., 2012).

It is evident from this analysis that the observed biogenic compounds are emitted within several hours of transport to the site, which can inform our exploration of the spatial distribution of emissions. Using the FLEXPART footprint modeling method (Gentner et al., 2014), we report the spatial distribution of biogenic sources that emit monoterpenes, which advect to the Bakersfield ground site. Figure 8 shows the distribution for the sum of monoterpenes over $6 \mathrm{~h}$ of transport, and Fig. S4 shows the distribution of individual chemical species. While many of the compounds appear to have similar sources in the San Joaquin Valley, some areas are larger emitters of different monoterpenes. The spatial distribution of monoterpene emissions observed in Bakersfield appears to be consistent with the location of croplands (Fig. S1), with agriculture to the northwest and east/southwest having the greatest area of influence. Yet influence from natural vegetation is expected, especially in the case of areas near or in the mountains with pine trees and other significant natural emitters of monoterpenes. While the emission distribution presented in Fig. 8 is mostly bounded to the valley floor, emissions from natural vegetation are potentially represented by areas in the foothills/mountains along the southern to eastern borders of the valley. Furthermore, natural vegetation surrounding the valley is a large source of reactive organic carbon emissions (Karl et al., 2013) and likely plays an important role in secondary pollutant formation, especially when mixed with anthropogenic $\mathrm{NO}_{\mathrm{x}}$ emissions (Shilling et al., 2013). These emissions are not observed in this study since they have largely been oxidized to secondary compounds that are outside the scope of our measurements. 


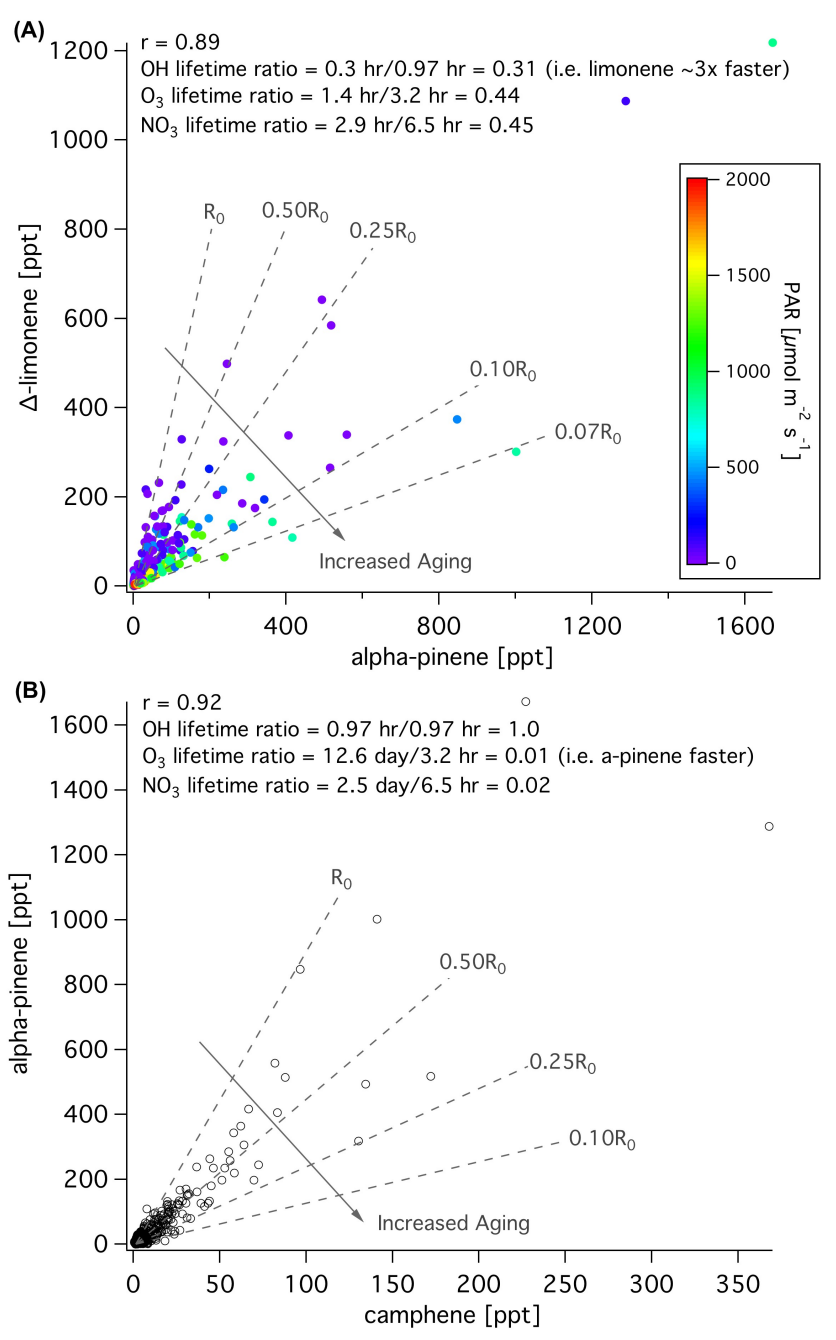

Figure 7. Observations of monoterpene pairs at the Bakersfield site. (A) $\Delta$-limonene vs. $\alpha$-pinene. Ratios of lifetimes to all three atmospheric oxidants show faster processing of $\Delta$-limonene. Given the concentrations of radicals, $\mathrm{OH}$ oxidation has the fastest timescales and the importance of $\mathrm{OH}$ oxidation is also indicated by the most aged parcels coinciding with PAR (representative of $\mathrm{OH}$ production). (B) A comparison of $\alpha$-pinene vs. camphene at Bakersfield shows evidence of aging by $\mathrm{O}_{3}$ and $\mathrm{NO}_{3}$ as $\alpha$-pinene and camphene's lifetimes to $\mathrm{OH}$ are identical.

\subsection{Impacts on air quality}

The principal motivation for studying biogenic emissions from agriculture was to improve our understanding of the impact of biogenic emissions on air quality in the San Joaquin Valley. Terpenoid compounds are known to be very reactive and have the potential to form both tropospheric ozone and SOA. Our work has highlighted orange trees as large emitters, but many other crops have been shown in this and other studies to have non-negligible emissions (Winer et al., 1992). Previous work has concluded that emissions from agricultural croplands are minor (Lamb et al., 1987). This may be

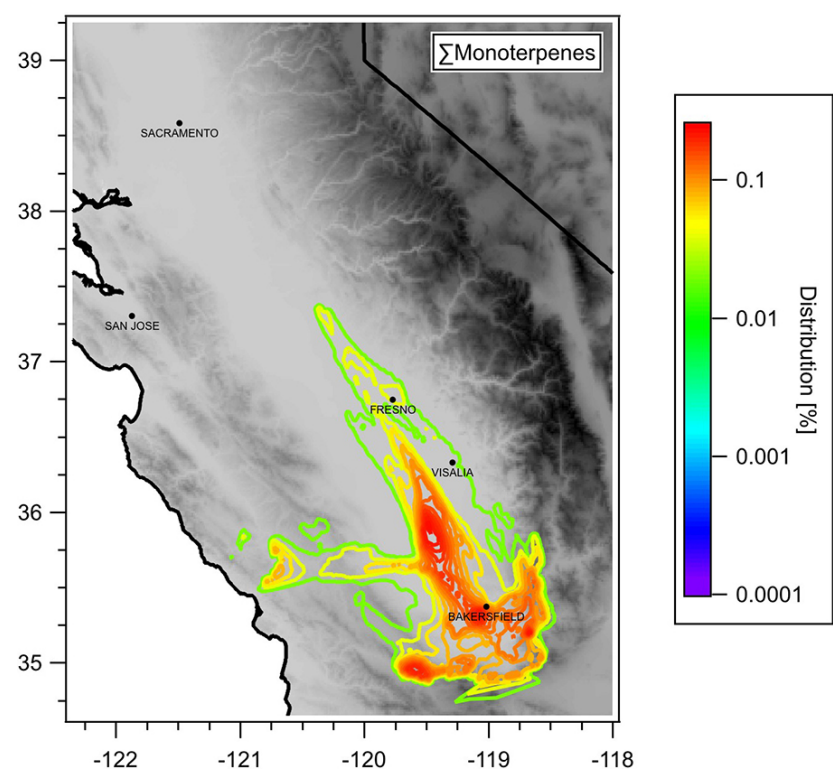

Figure 8. Spatial distribution of monoterpene sources in the southern San Joaquin Valley shown using the statistical source footprint of the sum of monoterpenes over $6 \mathrm{~h}$ of transport prior to arrival at the CalNex ground site in Bakersfield, CA.

true for some crop types, particularly with respect to the isoprene emissions. However, the extent of land coverage and leaf mass, together with the range of observed emission factors for all compound classes, is likely to result in croplands representing a significant fraction of biogenic emissions in agricultural regions.

\subsubsection{Relative magnitude of biogenic vs. anthropogenic emissions}

To provide a relative comparison for biogenic emissions in context of the region, we estimated the ambient concentration of anthropogenic emissions due to motor vehicles during the spring campaign at the rural Lindcove site using the source receptor modeling methods described in Gentner et al. (2012). For the purpose of comparison, the anthropogenic source contribution is focused on gasoline and diesel-related emissions. The biogenic source contribution is a sum of observed biogenic compounds (larger than isoprene), predominantly emitted by agriculture. Figure 6 shows the diurnal pattern and relative prevalence of anthropogenic and biogenic source contributions for both Lindcove and Bakersfield. Biogenic sources do not contribute substantial primary emissions in Bakersfield, but are very important at the Lindcove site, especially in the spring. This effect is due to the differences in the biogenic factor as the anthropogenic contribution is similar between the two sites except for peaks due to commuting periods in Bakersfield (Fig. 6b). While a similar source receptor analysis is not possible for the summer at Lindcove, a comparison of anthropogenic compounds 
(e.g., $m / p$-xylene, isooctane) between the two seasons shows that nighttime concentrations are similar, but daytime concentrations of motor vehicle emissions are $\sim 30 \%$ lower. This is likely due to a combination of enhanced photochemical processing and increased dilution during the summer months, when the top of the mixed boundary layer is generally higher. A comparison of diurnal average concentration ranges between sources shows that the summertime sum of monoterpenes (1-19 ppbC, Fig. 5a) was slightly lower than the springtime anthropogenic vehicular contribution (1446 ppbC, Fig. 6b). Together the results in this paper suggest that in rural parts of the San Joaquin Valley, anthropogenic emissions from motor vehicles will be slightly higher or the same order as summertime biogenic emissions of terpenoids.

During citrus tree flowering, the mass of observed biogenic compounds was on average 14 times that of inferred anthropogenic compounds from vehicular emissions at the Lindcove site. In contrast, the mass of anthropogenic contributions from motor vehicles was 48 times the observed monoterpenoids from biogenic sources in Bakersfield (Fig. 6). Contributions from isoprene or oxygenated VOCs from biogenic sources will slightly reduce this difference at Bakersfield, but are not included as these emissions cannot be attributed to agriculture.

Daytime monoterpene concentrations (i.e., sum of speciated monoterpenes measured via GC/MS) measured at Lindcove during spring were on average $6 \pm 1$ times concentrations in the summer. When considering potential differences in meteorological dynamics, this is largely consistent with observations from yearlong PTR-MS measurements at the Lindcove site that reported a 10 -fold increase in the monoterpene BEF between the flowering and non-flowering periods (Fares et al. 2012a). Given that the concentration of quantified flowering compounds in this work was 4 times the sum of monoterpenes (Fig. 2), in total flowering increases carbon emissions $\sim 30$-fold, with the non-monoterpene source profile for flowering shown in Table 6. This difference in emissions between flowering and non-flowering plants needs to be considered in emissions and air quality modeling, since the chemistry of the atmosphere may be significantly different during flowering periods. Such seasonal events should be taken into account to accurately model the large changes in biogenic emissions from agriculture and air quality in the San Joaquin Valley. Important emission events include spring flowering, pruning, harvesting, and fertilizer application (Fares et al., 2012a). During these events large increases in emissions of terpenoids were measured (monoterpenes, sesquiterpenes, and oxygenated terpenes). It is important to note that many agricultural regions, like the San Joaquin Valley, are comprised of a diverse mixture of crop types. These plants have different phonological and management cycles, meaning that emission events, such as flowering, will occur at different times and there is less likely to be a singular burst in emissions. The timing and intensity of these events will have to be determined for each major crop type in a region of interest.

\subsubsection{Ozone formation potential}

To assess the ability of agricultural terpenoid emissions and flowering events to impact air quality via the contributions of reactive precursors to ozone and $\mathrm{SOA}$, we developed metrics to compare them to motor vehicle emissions. The ability of a compound to produce ozone is quantified through the use of literature MIR values $\left[\mathrm{gO}_{3} \mathrm{~g}^{-1}\right.$ compound] (Carter, 2007). We use MIR to compare sources on a similar basis despite differences in $\mathrm{NO}_{\mathrm{x}}$ availability as the San Joaquin Valley has a complex spatial distribution of emissions and meteorology. Gasoline exhaust, diesel exhaust, and non-tailpipe emissions have MIR ozone formation potentials (OFPs) of 4.5, 2.5, and $2.0 \mathrm{gO}_{3} \mathrm{~g}^{-1}$, respectively (Gentner et al., 2013). For the monoterpene profile observed during the spring (including $p$-cymene), the OFP was calculated to be $4.1 \mathrm{gO}_{3} \mathrm{~g}^{-1}$. The flowering source profile in Table 6 has an OFP of 4.3$5.5 \mathrm{gO}_{3} \mathrm{~g}^{-1}$ with the range of potential values for unknown values determined from compounds with similar structures and general values provided with the framework. Linalool, which comprises $70 \%$ of the flowering profile, has a known OFP of $5.4 \mathrm{gO}_{3} \mathrm{~g}^{-1}$. These calculated values infer that per mass of emissions, the biogenic emissions have a greater ability to produce ozone than gasoline emissions. This effect may be slightly reduced as terpenoids are generally more reactive with ozone and will also act as a loss mechanism for tropospheric ozone. Overall, we observed that crops are relatively minor emitters of isoprene, a highly effective ozone precursor. Emissions of isoprene from natural vegetation, such as oak trees in the foothills surrounding the San Joaquin Valley, play an important role in ozone formation and must also be considered in modeling efforts.

\subsubsection{Secondary organic aerosol formation potential}

Predicting the exact SOA yields and formation from flowering-related compounds is not feasible given the high level of uncertainty associated with predicting SOA yields for these compounds, as many of them have barely been studied. However their potential to form SOA can be approximated using average oxidant concentrations and literature on well-characterized $\Delta$-limonene and $\alpha$-pinene yields from $\mathrm{OH}$ oxidation and ozonolysis experiments (Saathoff et al., 2009; Kim et al., 2012), and work by $\mathrm{Ng}$ et al. (2006) that compares a suite of terpenoid compounds including $\Delta$ limonene and $\alpha$-pinene. SOA yields from $\Delta$-limonene and $\alpha$-pinene range from 0.25 to 0.35 and 0.1 to $0.2 \mathrm{gOA} \mathrm{g}^{-1}$, respectively, for ozonolysis at an organic particle loading of $10 \mathrm{\mu g} \mathrm{m}^{-3}$ (Saathoff et al., 2009). SOA yields from $\mathrm{OH}$ oxidation under high- $\mathrm{NO}_{\mathrm{x}}$ conditions at similar particle loadings are significantly lower at approximately 0.05 and $0.03 \mathrm{gOA} \mathrm{g}^{-1}$ for $\Delta$-limonene and $\alpha$-pinene, respectively 
(Kim et al., 2012). Given the lifetimes to $\mathrm{OH}$ and $\mathrm{O}_{3}$ presented in this work, we calculate overall SOA yields of 0.1 and $0.05 \mathrm{gOA} \mathrm{g}^{-1}$ at $\mathrm{OA}=10 \mu \mathrm{g} \mathrm{m}^{-3}$. Atmospheric oxidation in low- $\mathrm{NO}_{\mathrm{x}}$ conditions will result in higher SOA yields, but here we restrict the comparison against other sources to the high- $\mathrm{NO}_{\mathrm{x}}$ conditions observed in the San Joaquin Valley. During the summer, monoterpene emissions were dominated by $\Delta$-limonene with a yield of $0.01 \mathrm{gOA} \mathrm{g}^{-1}$. Assessing the behavior of other monoterpenoids associated with flowering and their reaction rates with $\mathrm{OH}$ and $\mathrm{O}_{3}$ suggests a slightly lower SOA yield for $\beta$-myrcene (0.04) than $\alpha$-pinene and an SOA yield for linalool under 0.01. Overall, under similar loadings, the monoterpene emissions have a greater SOA yield than gasoline exhaust $\left(0.023 \pm 0.007 \mathrm{gOA} \mathrm{g}^{-1}\right)$, but lower than diesel exhaust $\left(0.15 \pm 0.07 \mathrm{gOA} \mathrm{g}^{-1}\right)$ (based on the yields for gasoline and diesel derived in Gentner et al., 2012). Estimating SOA yields for the benzenoids associated with flowering is much more difficult given the uncertainties, but SOA yields for $\mathrm{C}_{7-8}$ aromatics in Gentner et al. (2012) were approximately $0.05 \mathrm{gOA} \mathrm{g}^{-1}$ for $\mathrm{OH}$ oxidation at an organic particle loading of $10 \mu \mathrm{g} \mathrm{m}^{-3}$ and high- $\mathrm{NO}_{\mathrm{x}}$. So for this comparison, we conservatively assume a value of $0.05 \mathrm{gOA} \mathrm{g}^{-1}$ or greater for benzenoid compounds given their decreased initial volatility due to initially present functional groups. However, recent exploratory work on SOA produced from aqueous processing of phenolic compounds reported high SOA yields (Sun et al., 2010). In general, this work identifies the critical research needed to improve estimates of SOA yields from the biogenic compounds discussed in this study through theoretical or experimental studies.

\subsubsection{Overall comparison in San Joaquin Valley}

Detailed modeling using spatially resolved chemical models coupled with emissions will be necessary to fully understand the relative impact of biogenic emissions on air quality using the new information derived in this study. Here we use this information and the case study of the San Joaquin Valley in a back-of-the-envelope calculation to demonstrate the need for further modeling based on the magnitude of emissions from agricultural crops and their potential ozone and SOA. Spatial distribution of emissions and chemistry are essential to account for transport and $\mathrm{NO}_{\mathrm{x}}$ emissions/chemistry, but the objective here is to inform the necessity of that future research. The work presented here focuses on emissions of monoterpenoids and larger compounds, and does not include isoprene or small oxygenated VOCs and alcohols that are also emitted from vegetation. As the focus is on the relative impacts of agriculture, we do not consider the potential transport of emissions from natural vegetation (e.g., pine trees, oak trees) in the foothills or mountains. We use available metrics from the literature to assess potential ozone and SOA formation with the caveat that they may not fully capture the differences in $\mathrm{NO}_{\mathrm{x}}$ availability and thus the chemi-

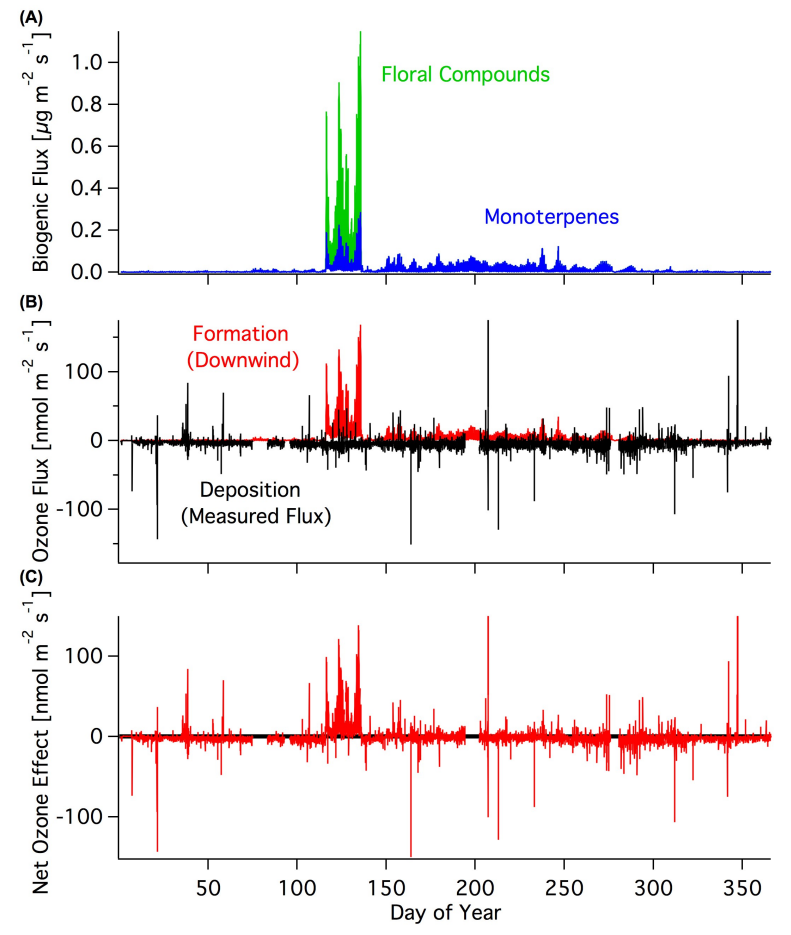

Figure 9. The components of the net ozone flux for the Lindcove orange orchard. (A) Modeled fluxes of monoterpenes and floral compounds are greatest in the spring during flowering, but are significant throughout the summer. Sesquiterpene emissions are assumed to be equivalent to monoterpene emissions. (B) Ozone formation and deposition fluxes per acre throughout the year show variable ozone formation with more constant deposition (stomatal and chemical). Formation is calculated as potential $\mathrm{O}_{3}$ (i.e., assuming a VOClimited regime). (C) The combined effect of these fluxes produces a net flux into the canopy except when biogenic emissions are high.

cal regimes between urban and rural areas in the valley. It is with these caveats that we estimate the magnitude of emissions from agricultural vegetation relative to motor vehicles and their potential to impact air quality.

Based on fuel sales for the valley and the results of Gentner et al. (2012, 2013), gas-phase gasoline exhaust emissions are $1.8 \times 10^{8} \mathrm{~g} \mathrm{day}^{-1}$, non-tailpipe gasoline emissions are $4.6 \times 10^{7} \mathrm{~g} \mathrm{day}^{-1}$, and diesel emissions are $4.6 \times 10^{7} \mathrm{gday}^{-1}$. Together this amounts to $2.7 \times 10^{8} \mathrm{~g} \mathrm{day}^{-1}$ and an ozone formation potential of $1.0 \times 10^{9} \mathrm{gO}_{3}$ day $^{-1}$, with the reactivity dominated by gasoline sources. Using the SOA yields from Gentner et al. (2012), potential SOA from motor vehicles is $8.0 \times 10^{6}$ gOA day $^{-1}$ (Table 8).

Biogenic emissions from agriculture are estimated using a range of emission factors from agriculture measured in the greenhouse study that is consistent with the range of input BEFs into the BEIGIS model; leaf-scale BEFs of 80 $3000 \mathrm{ngC} \mathrm{gDM}^{-1} \mathrm{~h}^{-1}$ correspond to field-level emission factors of $0.1-2 \mathrm{nmol} \mathrm{m}^{-2} \mathrm{~s}^{-1}$, given a mean specific leaf area 
Table 8. Metrics of secondary pollutant formation, emissions, and potential impacts of biogenic emissions from agricultural crops compared to motor vehicles in California's San Joaquin Valley.

\begin{tabular}{|c|c|c|c|c|c|}
\hline & \multirow{2}{*}{$\begin{array}{c}\text { Ozone formation } \\
\text { Potential } \\
{\left[\mathrm{gO}_{3} \mathrm{~g}^{-1}\right]}\end{array}$} & \multirow{2}{*}{$\begin{array}{l}\text { SOA yield } \\
{\left[\mathrm{gOA} \mathrm{g}^{-1}\right]}\end{array}$} & \multirow{2}{*}{$\begin{array}{c}\text { Emission estimates } \\
\text { for SJV } \\
{\left[10^{-7} \times \mathrm{g} \mathrm{d}^{-1}\right]}\end{array}$} & \multicolumn{2}{|c|}{ Potential production } \\
\hline & & & & $\begin{array}{c}\text { Ozone } \\
{\left[10^{-8} \times \mathrm{gO}_{3} \mathrm{~d}^{-1}\right]}\end{array}$ & $\frac{\mathrm{SOA}}{\left[10^{-6} \times \mathrm{gOAd}^{-1}\right]}$ \\
\hline Agriculture: monoterpenes & 4.1 & $\sim 0.1$ & $1-30^{\mathrm{a}}$ & $0.6-12$ & $1-30$ \\
\hline Agriculture: flowering compounds & $4.3-5.5$ & $\sim 0.03^{\mathrm{b}}$ & $24-720^{\mathrm{c}}$ & $10-400$ & $7.2-220$ \\
\hline Gasoline exhaust $\mathrm{d}^{\mathrm{d}}$ & 4.5 & $0.023 \pm 0.007$ & 18 & 8.0 & 2.7 \\
\hline Non-tailpipe gasoline emissions & 2.0 & $0.0024 \pm 0.0001$ & 4.6 & 0.93 & 0.1 \\
\hline Diesel exhaust ${ }^{\mathrm{d}}$ & 2.5 & $0.15 \pm 0.07$ & 4.6 & 1.2 & 5.1 \\
\hline
\end{tabular}

References: vehicular ozone formation potential values are MIR values from Gentner et al. (2013a).

${ }^{a}$ Range is set as $\mathrm{BEF}=80-3000 \mathrm{ngC} \mathrm{gDM}^{-1} \mathrm{~h}^{-1}$.

b SOA yield for flowering is lower estimate assuming a conservative yield of 0.05 for unstudied aromatics. Linalool (44\% of flowering source profile) has a very low SOA yield as well (0.007).

${ }^{\mathrm{c}}$ Estimated as 24 times baseline monoterpene emissions, and would also be accompanied by a factor of 5 increase in monoterpene emissions.

d Both gasoline and diesel exhaust include products of incomplete combustion (excluded in SOA calculations per Gentner et al. (2012)) and gasoline exhaust also includes cold start emissions (estimated as equivalent to $60 \%$ of gasoline running exhaust (Gentner et al., 2013a)).
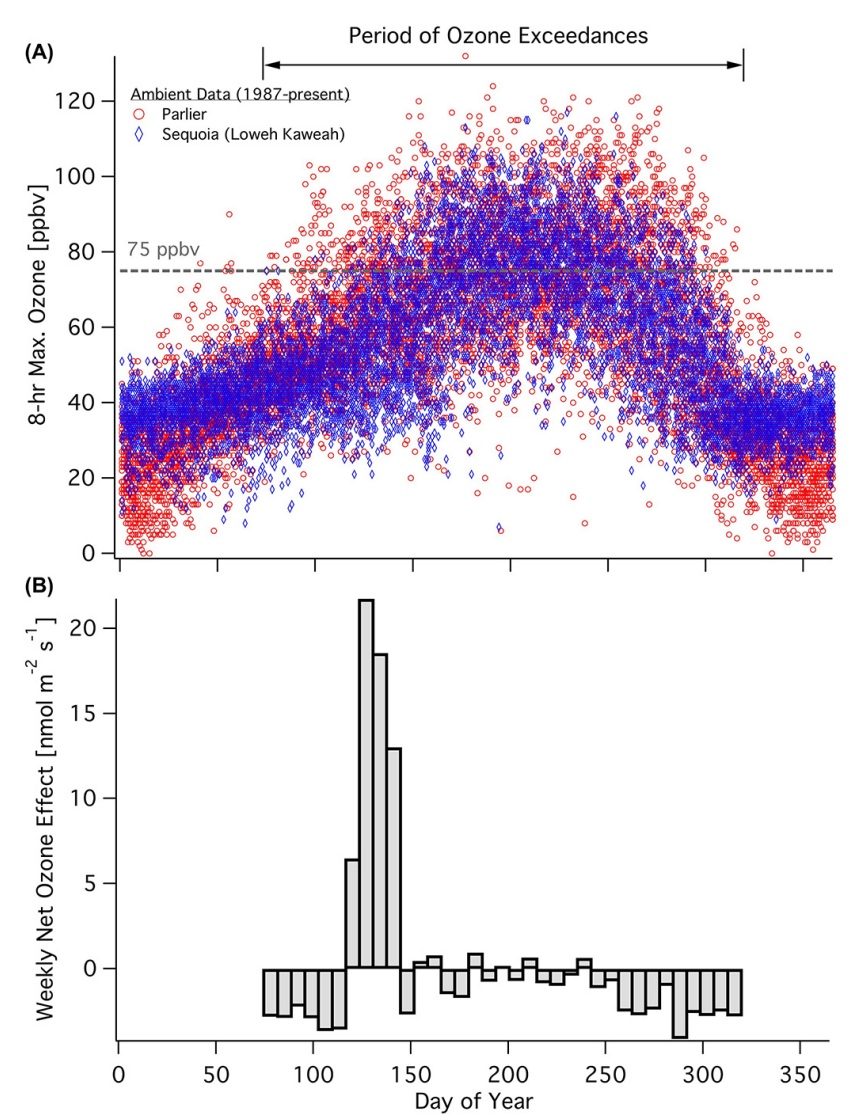

Figure 10. (A) Ambient ozone data since 1987 (CARB) show exceedances above $75 \mathrm{ppbv}$ at both the center of the valley and downwind in the Sierra Nevada with the primary period of concern from day 70 to 320 . No trends were apparent in the data from 1987 until present. (B) The weekly net effect of the orange orchard on ozone over this period is shown to be a net source of ozone in the springtime during flowering, and relatively neutral for most of the summer until the fall, when it becomes a sink. of $85 \mathrm{~cm}^{2} \mathrm{~g}^{-1}$ and a canopy leaf area index of $3.0 \mathrm{~m}^{2}$ leaf area $\mathrm{m}^{-2}$ land area (Fares et al., 2012b). These leaf mass density and leaf area factors are derived from the orange orchard, and are applied here with caution to the diversity of crops found in the valley. This range of estimates includes the summertime BEF measured in the orange orchard $\left(0.13 \mathrm{nmol} \mathrm{m}^{-2} \mathrm{~s}^{-1}\right)$ (Fares et al., 2012a). We assume a total land cover by agriculture of 3 million acres in the San Joaquin Valley (Table 1).

In terms of total mass from agricultural sources, baseline monoterpene emissions are estimated to be on the same order as anthropogenic sources, with a range of $0.1-3 \times 10^{8} \mathrm{~g} \mathrm{day}^{-1}$. The CARB emission inventory of $1.8 \times 10^{7} \mathrm{~g}$ monoterpenes day $^{-1}$ from agriculture in the San Joaquin Valley is at the low end of our estimated range. Our estimated emission factor is a lower limit since it does not include sesquiterpenes or emissions during flowering or other emission events, which may increase emissions by a factor of 30 or at least 2, respectively, with the timing depending on the diversity of crop types and management practices.

With regards to the production of ozone from organic precursors, monoterpene emissions from agriculture have the ability to produce $0.6-12 \times 10^{8} \mathrm{gO}_{3}$ day $^{-1}$, making them equally important as organic emissions from motor vehicles, but further analysis with $\mathrm{NO}_{\mathrm{x}}$ sensitivity is essential to elucidate the relative importance for the region. As this is a baseline value, it is evident that emissions occurring during flowering will have a major impact on ozone production given the substantial increase in emissions, and additional considerations for sesquiterpene emissions will increase ozone production as well.

Estimating SOA has a significant amount of uncertainty associated with it, but for comparison with motor vehicles we estimate that monoterpene emissions from agriculture can contribute $1-30 \times 10^{6} \mathrm{gOA} \mathrm{day}^{-1}$, across the range of emissions and SOA yields (at $10 \mu \mathrm{g} \mathrm{m}^{-3}$ ). This means that baseline monoterpene emissions have a similar ability to motor 
vehicles $\left(8.0 \times 10^{6} \mathrm{gOA} \mathrm{day}^{-1}\right)$ to produce SOA, which does not include sesquiterpene emissions or other emission events such as flowering. The valley-wide magnitude of flowering emissions is highly uncertain and warrants further work. Rough estimates with a range of flowering emissions are given with potential ozone and SOA formation in Table 8.

\subsubsection{Citrus: a case study on the net effect of agricultural crops on ozone uptake and formation}

Many woody plants, including orange trees, remove some ozone from the ambient atmosphere via uptake through their stomata. This process, stomatal deposition, along with soil/plant surface deposition and the reaction of ozone with reactive biogenic compounds in the air produces a flux of ozone into the plant canopy, which was measured for a full year at the Lindcove field site. Chemical deposition via reaction with biogenic volatile organic compounds (BVOCs) was estimated to be $10-26 \%$, while stomatal deposition and soil deposition were each responsible for approximately $\sim 30 \%$ of ozone losses (Fares et al., 2012b). A full discussion of these fluxes and their partitioning into different mechanisms has been published in Fares et al. (2012b).

To determine the net effect of the orange orchard on regional ozone, we compared the measured ozone flux into the canopy with the amount of ozone likely to be produced downwind based on emissions and OFP values. Monoterpene BEFs from the field site for spring and summer were used from Fares et al. (2012a), with the summer flux multiplied by 2 during non-flowering emission events (harvest, pruning, fertilizer application) when emissions measured by PTR-MS exceeded modeled emissions. Based on the work of Ormeno et al. (2010), sesquiterpene emissions were assumed to be equivalent to monoterpene emissions and were assumed to have an OFP of $4 \mathrm{gO}_{3} \mathrm{~g}^{-1}$ based on the range of potential OFPs. Emissions of floral compounds during the spring flowering period were estimated by multiplying monoterpene emissions by 4.0 per the results of Fig. 2. Additionally, downwind chemical removal of ozone beyond the measured flux reported previously (Fares et al., 2012b) was accounted for using the monoterpene emissions and the probability of reaction with ozone. Figure 9 summarizes the results of this analysis with total emissions, ozone fluxes into the canopy, ozone production, and the net effect. The net effect on a weekly timescale of these processes is shown in Fig. 10 over the period of ozone exceedances in the region. The orchard is a net source of ozone in the springtime during flowering, and is neither a major source nor sink for most of the summer. The orchard is a sink in the fall and in the early spring before flowering begins. Given that flowering occurs at different times for different crops throughout the valley, net ozone production during flowering may not translate to a valley-wide effect. The effect of ozone deposition was not included in the basin-wide comparison of agriculture to motor vehicles (Sect. 3.5.4) as exhaust emissions contain significant amounts of alkenes that can also remove ozone initially.

\subsubsection{Implications}

This work has demonstrated the importance of biogenic organic carbon emissions from agricultural crops relative to vehicular emissions in terms of total emissions and the formation of ozone and SOA in the San Joaquin Valley. Further highly resolved modeling of emissions and chemistry is warranted based on this new information. Recent work examined flowering emissions in the urban area of Boulder, $\mathrm{CO}$, and temporarily incorporated flowering into the MEGAN model (Baghi et al., 2012). The study concluded the impacts of flowering in Boulder, $\mathrm{CO}$, were minor (equivalent to $11 \%$ of the monoterpene flux). Our results suggest a larger annual temporary impact of flowering in agricultural regions with high densities of flowering foliage, but it is dependent on the composition of crops and flowering timing. When the magnitude of the flowering event is considered across a region, it may have a substantial effect on the biogenic emission inventory and likely on atmospheric composition and air quality, especially in regions prone to air quality problems. Orange tree flowering lasted for approximately one month, but the duration of flowering varies between plant species. It is important to note that most of the flowering occurs in the spring, conveniently before the greatest frequency of ozone exceedances in the San Joaquin Valley during summer, when contributions to ozone precursors would be more important.

The newly characterized compounds in this study should be included in the MEGAN and BEIGIS models since their emissions during flowering were on the same order as or greater than all the terpenoids observed. Further work is necessary to better characterize the basal emission factors, dependent parameters, and, in the case of the novel compounds, their ozone and SOA formation potential. Emissions due to flowering and other seasonal events need to be assessed for other major crops, and possibly natural vegetation. The modeling of biogenic emissions from agriculture has a major advantage over natural vegetation: the ability to gain more detailed information on the composition of vegetation species. These data, along with emission factors, provide the necessary components to more regional emissions and potentially identify potential regional changes in emissions with shifts or rotations in crop plantings.

The Supplement related to this article is available online at doi:10.5194/acp-14-5393-2014-supplement. 
Acknowledgements. We would like to acknowledge the California Air Resources Board (contract no. 06-329) and the Citrus Research Board for their support. This work does not carry the endorsement of either funding agency nor has it been reviewed by them. We thank Alex Guenther (NCAR) for his valuable comments and discussion of the manuscript. We would also like to thank Jim and Milo Gordon, Megan McKay, Joshua Pepper, Raymond Lo, Kurt Schmidt, Mark Sabin, and staff of the Oxford Tract Greenhouse (UC Berkeley) and the UC Cooperative Extension centers at Lindcove and Bakersfield.

Edited by: J. Rinne

\section{References}

Afsharypuor, S. and Jamali, M.: Volatile Constituents of the Flowering Aerial Parts, Fruits and Roots of Cardaria draba L., J. Essent. Oil Res., 18, 674-675, 2006.

Arey, J., Corchnoy, S. B., and Atkinson, R.: Emission of linalool from Valencia orange blossoms and its observation in ambient air, Atmos. Environ., 25, 1377-1381, 1991a.

Arey, J. Winer, A. M., Atkinson, R., Aschmann, S. M., Long, W. D., Morrison, C. L., and D. M. Olszyk.: Terpenes emitted from agricultural species found in California's Central Valley, J. Geophys. Res. 96, 9329-9336, 1991b.

Arey, J., Winer, A. M., Atkinson, R., Aschmann, S. M., Long, W. D., and Morrison, C. L.: Emission of (Z)-3-hexen-1-ol, (Z)-3hexeylacetate and other oxygenated hydrocarbons from agricultural plant species. Atmos. Environ., 25A, 1063-1075, 1991c.

Arey, J. Winer, A. M., Atkinson, R., Aschmann, S. M., Long, W. D., Morrison, C. L., and Olszyk, D. M.: Terpenes emitted from agricultural species found in California's Central Valley. J. Geophys. Res. 96, 9329-9336, 1991d.

Atkinson, R. and Arey, J.: Gas-phase tropospheric chemistry of biogenic volatile organic compounds: A review, Atmos. Environ., 37, S197-S219, 2003a.

Atkinson, R. and Arey, J.: Atmospheric degradation of volatile organic compounds, Chem. Rev., 103, 4605-4638, 2003 b.

Azuma, H., Toyota, M., and Asakawa, Y.: Intraspecific Variation of Floral Scent Chemistry in Magnolia kobus DC. (Magnoliaceae), J. Plant Res., 114, 411-422, 2001.

Baghi, R., Helmig, D., Guenther, A., Duhl, T., and Daly, R.: Contribution of flowering trees to urban atmospheric biogenic volatile organic compound emissions, Biogeosciences, 9, 3777-3785, doi:10.5194/bg-9-3777-2012, 2012.

Bendimerad, N., Bendiab, S. A. T., Breme, K., and Fernandez, X.: Essential Oil Composition of Aerial Parts of Sinapis arvensis L. from Algeria, J. Essent. Oil Res., 19, 206-208, 2007.

Bernhardt, P., Sage, T., Weston, P., Azuma, H., Lam, M., Thien, L. B., and Bruhl, J.: The pollination of Trimenia moorei (Trimeniaceae): floral volatiles, insect/wind pollen vectors and stigmatic self-incompatibility in a basal angiosperm, Ann. Bot., 92, 445458, 2003.

Bouvier-Brown, N. C., Goldstein, A. H., Gilman, J. B., Kuster, W. C., and de Gouw, J. A.: In-situ ambient quantification of monoterpenes, sesquiterpenes, and related oxygenated compounds during BEARPEX 2007: implications for gas- and particle-phase chemistry, Atmos. Chem. Phys., 9, 5505-5518, doi:10.5194/acp-9-5505-2009, 2009.
Brioude, J., Angevine, W. M., McKeen, S. A., and Hsie, E.Y.: Numerical uncertainty at mesoscale in a Lagrangian model in complex terrain, Geosci. Model Dev., 5, 1127-1136, doi:10.5194/gmd-5-1127-2012, 2012.

Brown, S. S., deGouw, J. A., Warneke, C., Ryerson, T. B., Dubé, W. P., Atlas, E., Weber, R. J., Peltier, R. E., Neuman, J. A., Roberts, J. M., Swanson, A., Flocke, F., McKeen, S. A., Brioude, J., Sommariva, R., Trainer, M., Fehsenfeld, F. C., and Ravishankara, A. R.: Nocturnal isoprene oxidation over the Northeast United States in summer and its impact on reactive nitrogen partitioning and secondary organic aerosol, Atmos. Chem. Phys., 9, 3027-3042, doi:10.5194/acp-9-3027-2009, 2009.

California Air Resources Board: Estimated annual average emissions - 2010, available at: http://www.arb.ca.gov/ei/emsmain/ emsmain.htm, last access August 2012.

California Department of Transportation: California Motor Vehicle Stock Travel, and Fuel Forecast (MVSTAFF) 2008 Report, available at http://www.dot.ca.gov/hq/tsip/otfa/tab/documents/ mvstaff/mvstaff08.pdf, last access: April 2012.

Carter, W. P. L.: SAPRC Atmospheric Chemical Mechanisms and VOC Reactivity Scales, 2007, available at: http://www.engr.ucr. edu/ carter/SAPRC/, last access: August 2012.

Ciccioli, P., Brancaleoni, E., Frattoni, M., Di Palo, V., Valentini, R., Tirone, G., Seufert, G., Bertin, N., Hansen, U., Csiky, O., Lenz, R., and Sharma, M.: Emission of reactive terpene compounds from orange orchards and their removal by within-canopy processes, J. Geophys. Res., 104, 8077-8094, 1999.

Di Carlo, P., Brune, W. H., Martinez, M., Harder, H., Lesher, R., Ren, X., Thornberry, T., Carroll, M. A., Young, V., Shepson, P. B., Riemer, D., Apel, E., and Campbell, C.: Missing $\mathrm{OH}$ reactivity in a forest: Evidence for unknown reactive biogenic VOCs, Science, 304, 722-725, 2004.

Donahue, N. M., Henrya, K. M., Mentel, T. F., Kiendler-Scharr, A., Spindler, C., Bohn, B., Brauers, T., Dorn, H. P., Fuchs, H., Tillmann, R., Wahner, A., Saathoff, H., Naumann, K.-H., Mohler, O., Leisner, T., Muller, L., Reinnig, M.-C., Hoffmann, T., Salo, K., Hallquist, M., Frosch, M., Bilde, M., Tritscher, T., Barmet, P., Praplan, A. P., DeCarlo, P. F., Dommen, J., Prevot, A. S. H., and Baltensperger, U.: Aging of biogenic secondary organic aerosol via gas-phase $\mathrm{OH}$ radical reactions, Proc. Natl. Acad. Sci. USA, 109, 13503-13508, 2012.

Estimation Programs Interface Suite for Microsoft Windows, AOPWIN v.1.92, United States Environmental Protection Agency, Washington DC, USA, available at: http://www.epa.gov/opptintr/ exposure/pubs/episuitedl.htm, 2000.

Fall, R., Karl, T., Hansel, A., Jordan, A., and Lindinger, W.: Volatile organic compounds emitted after leaf wounding: on-line analysis by proton-transfer-reaction mass spectrometry. J. Geophys. Res., 104, 15963-15974, 1999.

Fares, S., Gentner, D. R., Park, J. H., Ormeño, E., Karlik, J., and Goldstein, A. H.: Biogenic emissions from Citrus species in California, Atmos. Environ., 45, 4557-4568, 2011.

Fares, S., Park, J.-H., Gentner, D. R., Weber, R., Ormeño, E., Karlik, J., and Goldstein, A. H.: Seasonal cycles of biogenic volatile organic compound fluxes and concentrations in a California citrus orchard, Atmos. Chem. Phys., 12, 9865-9880, doi:10.5194/acp12-9865-2012, 2012a. 
Fares, S., Weber, R., Park, J. H., Gentner, D. R., Karlik, J., and Goldstein, A. H.: Ozone deposition to an orange orchard: Partitioning between stomatal and non-stomatal sinks, Environ. Pollut., 169, 258-266, 2012b.

Freitas, J. A., Maluf, W. R., Cardoso, M. D., Gomes, L. A. A., and Bearzotti, E.: Inheritance of foliar zingiberene contents and their relationship to trichome densities and whitefly resistance in tomatoes, Euphytica, 127, 275-287, 2002.

Gentner, D. R., Isaacman, G., Worton, D. R., Chan, A. W., Dallmann, T. R., Davis, L., Liu, S., Day, D. A., Russell, L. M., Wilson, K. R., Weber, R., Guha, A., Harley, R. A., Goldstein, A. H.: Elucidating secondary organic aerosol from diesel and gasoline vehicles through detailed characterization of organic carbon emissions, P. Natl. Acad. Sci. USA, 109, 18318-18323, 2012.

Gentner, D. R., Worton, D. R., Isaacman, G., Davis, L., Dallmann, T. R. Wood, E. C. Herndon, S. C, Goldstein, A. H., and Harley, R. A.: Chemical speciation of gas-phase organic carbon emissions from motor vehicles and implications for ozone production potential, Environ. Sci. Technol., 47, 11837-11848, 2013.

Gentner, D. R., Ford, T. B., Guha, A., Boulanger, K., Brioude, J., Angevine, W. M., de Gouw, J. A., Warneke, C., Gilman, J. B., Ryerson, T. B., Peischl, J., Meinardi, S., Blake, D. R., Atlas, E., Lonneman, W. A., Kleindienst, T. E., Beaver, M. R., Clair, J. M. St., Wennberg, P. O., VandenBoer, T. C., Markovic, M. Z., Murphy, J. G., Harley, R. A., and Goldstein, A. H.: Emissions of organic carbon and methane from petroleum and dairy operations in California's San Joaquin Valley, Atmos. Chem. Phys., 14, 4955-4978, doi:10.5194/acp-14-4955-2014, 2014.

Goldstein, A. H. and Galbally, I. E.: Known and Unexplored Organic Constituents in the Earth's Atmosphere, Environ. Sci. Technol., 41, 1514-1521, 2007.

Guenther, A., Zimmerman, P. R., Harley, P. C., Monson, R. K., and Fall, R.: Isoprene and monoterpene emission rate variability - model evaluations and sensitivity analyses, J. Geophys. Res.Atmos., 98, 12609-12617, 1993.

Guenther, A. B., Jiang, X., Heald, C. L., Sakulyanontvittaya, T., Duhl, T., Emmons, L. K., and Wang, X.: The Model of Emissions of Gases and Aerosols from Nature version 2.1 (MEGAN2.1): an extended and updated framework for modeling biogenic emissions, Geosci. Model Dev., 5, 1471-1492, doi:10.5194/gmd-51471-2012, 2012.

Hansen, U. and Seufert, G.: Terpenoid emission from Citrus sinensis (L.) OSBECK under drought stress, Phys. Chem. Earth Pt. B, 24, 681-687, 2003.

Helmig, D., Ortega, J., Guenther, A., Herrick, J. D., and Geron, C.: Sesquiterpene emissions from loblolly pine and their potential contribution to biogenic aerosol formation in the Southeastern US, Atmos. Environ., 40, 4150-4157, 2006.

Holzinger, R., Lee, A., Paw, K. T., and Goldstein, U. A. H.: Observations of oxidation products above a forest imply biogenic emissions of very reactive compounds, Atmos. Chem. Phys., 5, 67-75, doi:10.5194/acp-5-67-2005, 2005.

Jansen R. M. C., Miebach, M., Kleist, E., van Henten, E. J., and Wildt, J.: Release of lipoxygenase products and monoterpenes by tomato plants as an indicator of Botrytis cinerea-induced stress, Plant Bio., 11, 859-868, 2008.

Karl, T., Misztal, P. K., Jonsson, H. H., Shertz, S., Goldstein, A. H., and Guenther, A. B.: Airborne Flux Measurements of BVOCs above Californian Oak Forests: Experimental Investigation of
Surface and Entrainment Fluxes, OH Densities, and Damköhler Numbers, J. Atmos. Sci., 70, 3277-3287, doi:10.1175/JASD-13-054.1, 2013.

Karlik, J. F., McKay, A. H., Welch, J. M., and Winer, A. M.: A survey of California plant species with a portable VOC analyzer for biogenic emission inventory development. Atmos. Environ. 36, 5221-5233, 2002.

Kim, H., Barkey, B., Paulson, S. E.: Real Refractive Indices and Formation Yields of Secondary Organic Aerosol Generated from Photooxidation of $\Delta$-limonene and $\alpha$-Pinene: The Effect of the HC/NOx Ratio, J. Phys. Chem. A, 116, 6059-6067, 2012.

Kotze, M. J., Jürgens, A., Johnson, S. D., and Hoffmann, J. H.: Volatiles associated with different flower stages and leaves of Acacia cyclops and their potential role as host attractants for Dasineura dielsi (Diptera: Cecidomyiidae), S. Afri. J. Bot., 76, 701-709, 2010.

Lewis, G. P., Knudsen, J. T., Klitgaard, B. B., and Pennington, R. T.: The floral scent of Cyathostegia mathewsii (Leguminosae, Papilionoideae) and preliminary observations on reproductive biology, Biochem. Syst. Ecol., 31, 951-962, 2003.

Ng, N. L., Kroll, J. H., Kenwood, M. D., Bahreini, R., Varutbangkul, V., Flagain, R. C., Seinfeld, J. H., Lee, A., and Goldstein, A. H.: Contribution of first- versus second-generation products to secondary organic aerosols formed in the oxidation of biogenic hydrocarbons, Environ. Sci. Technol., 40, 2283-2297, 2006.

Omura, H., Honda, K., and Hayashi, N.: Chemical and chromatic bases for preferential visiting by the cabbage butterfly, Pieris rapae, to rape flowers, J. Chem. Ecol., 25, 1895-1906, 1999.

Ormeño, E., Fernandez, C., Bousquet-Mélou, A., Greff, S., Morin, E., Robles, C., Vila, B., and Bonin, G.: Monoterpene and sesquiterpene emissions of three Mediterranean species through calcareous and siliceous soils in natural conditions. Atmos. Environ., 41, 629-639, 2007,

Ormeño, E., Gentner, D. R., Fares, S., Karlik, J., Park, J.-H., and Goldstein, A. H.: Sesquiterpenoid emissions from agricultural crops: correlations to monoterpenoid emissions and leaf terpene content, Environ. Sci. Technol., 44, 3758-3764, 2010.

Pollmann, J., Ortega, J., and Helmig, D.: Analysis of atmospheric sesquiterpenes: Sampling losses and mitigation of ozone interferences, Environ. Sci. Technol., 39, 9620-9629, 2005.

Rollins, A. W., Browne, E. C., Min, K. E., Pusede, S. E., Wooldridge, P. J., Gentner, D. R., Goldstein, A. H., Liu, S., Day, D. A., Russell, L. M., and Cohen, R. C.: Nighttime growth of particulate organic nitrates: a significant source of atmospheric secondary organic aerosols, Science, 337, 2010-1212, 2012.

Saathoff, H., Naumann, K. H., Mohler, O., Jonsson, A. M., Hallquist, M., Kiendler-Scharr, A., Mentel, T. F., Tillmann, R., and Schurath, U.: Temperature dependence of yields of secondary organic aerosols from the ozonolysis of a-pinene and $\Delta$-limonene, Atmos. Chem. Phys., 9, 1551-1577, doi:10.5194/acp-9-15512009, 2009.

Sakulyanontvittaya, T., Duhl, T., Wiedinmyer, C., Helmig, D., Matsunaga, S., Potosnak, M., Milford, J., and Guenther, A. B.: Monoterpene and Sesquiterpene Emission Estimates for the United States, Environ. Sci. Technol., 42, 1623-1629 2008.

Scott, K. I.: Appendix B: Development of a biogenic hydrocarbon emission inventory for the Central California Ozone Study domain, in: Ozone SIP Modeling Documentation and Results for the Sacramento Region Using the July/August 2000 Cen- 
tral California Ozone Study Episode, California Air Resources Board, available at: http://eos.arb.ca.gov/eos/ARB_Modeling/ JulyAug2000_SIP_Modeling_Doc_AppB_11-26-03.pdf, 2003.

Shilling, J. E., Zaveri, R. A., Fast, J. D., Kleinman, L., Alexander, M. L., Canagaratna, M. R., Fortner, E., Hubbe, J. M., Jayne, J. T., Sedlacek, A., Setyan, A., Springston, S., Worsnop, D. R., and Zhang, Q.: Enhanced SOA formation from mixed anthropogenic and biogenic emissions during the CARES campaign, Atmos. Chem. Phys., 13, 2091-2113, doi:10.5194/acp-13-2091-2013, 2013.

Spracklen, D. V., Jimenez, J. L., Carslaw, K. S., Worsnop, D. R., Evans, M. J., Mann, G. W., Zhang, Q., Canagaratna, M. R., Allan, J., Coe, H., McFiggans, G., Rap, A., and Forster, P.: Aerosol mass spectrometer constraint on the global secondary organic aerosol budget, Atmos. Chem. Phys., 11, 12109-12136, doi:10.5194/acp-11-12109-2011, 2011.

Sun, Y. L., Zhang, Q., Anastasio, C., and Sun, J.: Insights into secondary organic aerosol formed via aqueous-phase reactions of phenolic compounds based on high resolution mass spectrometry, Atmos. Chem. Phys., 10, 4809-4822, doi:10.5194/acp-104809-2010, 2010.
Tingey, D., Manning, M., Grothaus, L., and Burns, W.: Influence of light and temperature on monoterpene emission rates from slash pine, Plant Phys., 65, 797-801, 1980.

US Environmental Protection Agency, US Clean Air Act (and subsequent amendments/rulings), available at: http://www.epa.gov/ air/caa/, last access: June 2012.

van Schie, C. C. N., Haring, M. A., and Schuurink, R. C.: Tomato linalool synthase is induced in trichomes by jasmonic acid, Plant Mol. Biol., 64, 251-263, 2007.

Vieira, R. C., Delprete, P. G., Leitao, G. G., and Leitao, S. G.: Anatomical and chemical analyses of leaf secretory cavities of Rustia formosa (Rubiaceae), Am. J. Bot., 88, 2151-2156, 2001.

Winer, A. M., Arey, J., Atkinson, R., Aschmann, S. M., Long, W. D., Morrison, C. L., and Olszyk, D. M.: Hydrocarbon emissions from vegetation found in California's Central Valley. Final Report to the California Air Resources Board, Contract No. A732$155,1989$.

Winer, A. M., Arey, J., Atkinson, R., Aschmann, S. M., Long, W. D., Morrison, C. L., and Olszyk, D. M.: Emission rates of organics from vegetation in California's Central Valley, Atmos. Environ., 26, 2647-2659, 1992. 